\title{
Economic policy uncertainty and bank stability
}

\author{
Gamze Ozturk Danisman ${ }^{\mathrm{a}}$, Amine Tarazi ${ }^{\mathrm{bc}}$ \\ ${ }^{a}$ Faculty of Economics, Administrative and Social Sciences, Kadir Has University, Turkey \\ ${ }^{\mathrm{b}}$ Université de Limoges, LAPE, 5 rue Félix Eboué BP 3127, 87031 Limoges Cedex 1, France \\ ${ }^{\mathrm{c} I n s t i t u t ~ U n i v e r s i t a i r e ~ d e ~ F r a n c e ~(I U F), ~} 1$ rue Descartes, 75231 Paris Cedex 05, France
}

This draft: 25 May 2021

Please do not quote without the permission of the authors.

\begin{abstract}
We examine the influence of economic policy uncertainty on bank stability post-2007-2008 global financial crisis. We rely on the economic policy uncertainty (EPU) index introduced by Baker et al. (2016). We use 176,477 quarterly observations for US commercial banks over the period from 2011Q1 to 2020Q3 and find consistent and robust evidence that bank stability decreases as the level of economic policy uncertainty increases. We specifically control for demand-side effects which indicates that the decrease in bank stability not only originates from borrowers' and customers' conditions but also from a change in bank behavior. A deeper investigation shows that the negative impact of policy uncertainty on bank stability is stronger for larger banks, and weaker for highly capitalized banks as well as for more liquid banks. Our findings have important implications particularly for the COVID-19 policy implementations.
\end{abstract}

JEL classification: G18, G21, G28

Keywords: Economic Policy Uncertainty, Bank Stability, Bank Risk, COVID-19

\footnotetext{
${ }^{a}$ Email: gamze.danisman@khas.edu.tr (G. O.Danisman)

${ }^{b c}$ Email: amine.tarazi@unilim.fr (A.Tarazi)
} 


\title{
Economic policy uncertainty and bank stability
}

\begin{abstract}
We examine the influence of economic policy uncertainty on bank stability post-2007-2008 global financial crisis. We rely on the economic policy uncertainty (EPU) index introduced by Baker et al. (2016). We use 176,477 quarterly observations for US commercial banks over the period from 2011Q1 to 2020Q3 and find consistent and robust evidence that bank stability decreases as the level of economic policy uncertainty increases. We specifically control for demand-side effects which indicates that the decrease in bank stability not only originates from borrowers' and customers' conditions but also from a change in bank behavior. A deeper investigation shows that the negative impact of policy uncertainty on bank stability is stronger for larger banks, and weaker for highly capitalized banks as well as for more liquid banks. Our findings have important implications particularly for the COVID-19 policy implementations.
\end{abstract}

JEL classification: G18, G21, G28

Keywords: Economic Policy Uncertainty, Bank Stability, Bank Risk, COVID-19 


\section{Introduction}

After the Great Recession, policymakers have taken many steps, and bank regulators have tightened existing rules such as minimum capital requirements and introduced new rules such as liquidity rules, amongst others. The aim was to strengthen banks against future shocks. A decade after the crisis, even though banks have become safer with important buffers, the recovery period has been quite sluggish in the US, claimed to be slower than the typical recovery periods from severe financial crises (Papell and Prodan, 2012; Taylor, 2014). According to the Federal Open Market Committee (2009) and the IMF (2012, 2013), fiscal, regulatory, and monetary uncertainties could have contributed to the slow recovery since the end of the crisis in 2009. New sources of risk and uncertainty have appeared in the US, such as the partisan policy conflicts, uncertainty regarding fiscal, regulatory, and monetary policies, increases in government spending, taxes and regulation, political interference in the policymaking process, the tight presidential elections, etc. (Baker et al. 2014, 2016). At times when the disagreement between policymakers on fiscal, monetary, or regulatory matters increases, as it happened globally and, in the US, post-2007-2008 global financial crisis, the overall level of uncertainty also intensifies (Kaviani et al. 2020).

These developments have raised concerns regarding the potential negative consequences of economic policy uncertainty (EPU) on the economy, and new methodologies have been implemented to more appropriately capture time-varying economic policy uncertainty (Baker et al. 2016), partisan policy conflict (Azzimonti, 2018), and macroeconomic uncertainty (Jurado et al. 2015). There is a growing interest of scholars and policymakers on how policy-related uncertainty impacts economic and financial activities. Uncertainty about government economic policies has severe implications on the real economy, such as reducing corporate investment (Julio and Yook, 2012; Gulen and Ion, 2016), decreasing merger and acquisitions (Nguyen and Phan, 2017; Bonaime et al. 2018), reducing the sensitivity of investment to the cost of capital (Drobetz et al. 2018), increasing corporate credit spread (Kaviani et al. 2020), among others. Karnizova and Li (2014) find that after controlling for the standard financial variables that help to predict recessions, economic policy uncertainty is still a statistically and economically significant predictor of US recessions. Despite the amount of literature on its influence on the real economy, whether economic policy uncertainty impacts financial institutions, particularly banks, has been relatively less explored. Some papers have explored the influence of EPU on bank lending (Nguyen et al. 2020; Bordo et al. 2016; Hu and Gong, 2019; Bilgin et al. 2021; Biswas and Zhai, 2021). Others have looked at its impact on loan pricing (Ashraf and Shen, 2019), loan contracts (Huang et al. 2020), capital shortages (Matousek et al. 2020) or bank liquidity hoarding (Berger et al. 2020).

This paper investigates the influence of economic policy uncertainty on bank stability for a sample of US commercial banks ${ }^{2}$. Policy-related uncertainty has many implications for the safety and soundness of the banking system. The 2007-2008 global financial crisis has raised significant qualms on whether banks have the proper incentives to effectively manage their risk in the best interests of depositors and investors (Altunbas et al., 2011). As a response, the DoddFrank Act was introduced in 2010, which contains numerous regulatory and supervisory provisions to promote financial stability in the US and to be implemented over several years.

\footnotetext{
${ }^{2}$ To our knowledge, Phan et al. (2020) and Karadima and Louri (2020) are the only studies exploring this link; the former uses a cross-country sample for 23 countries, and the latter uses a sample of four major euro area countries, respectively. While these studies document the negative impact of economic policy uncertainty on bank stability, they do not distinguish between demand-side effects and supply-side effects to capture actual changes in bank behavior driven by changes in economic policy uncertainty.
} 
However, the complexities in the Dodd-Frank rules and delays in its implementation have brought regulatory policy uncertainty for banks (Taylor, 2014; Bordo et al., 2016). Besides, due to the regulatory deficiencies revealed by the 2007-2008 global financial crisis, the Basel Committee on Banking Supervision (BCBS) introduced reforms in December 2010, known as Basel III. The aim of Basel III is to promote the resilience of the financial industry by bringing more stringency on capital requirements, and it introduces new liquidity rules (BCBS, 2010). It is argued that the ultra-low interest rate monetary policy environment, regulatory burdens, and ambiguities in economic policies might have resulted in unintended consequences on banks, such as increased pressure on banks' profitability. This might have led them to search for higher yield, increasing moral hazard and risky behavior (Bekaert et al., 2013). As seen in Figure A1 Panels A-C in the Appendix, average quarterly bank stability, measured by the average Z-score and the averages of its components (risk-adjusted capitalization and riskadjusted profitability), have all been quite volatile in the US during the 2011-2020 period. Though Panel D is showing that bank failures have been declining over the 2011-2020 period, there are concerns that bank failures are likely to increase in 2021 and after because the COVID19 is expected to result in a significant surge in loan defaults and generate other stressful conditions for banks ${ }^{3}$.

Theoretically, two opposing views on the potential impact of uncertainty on bank risk are prevalent. On the one hand, according to the real options theory, the probability of making wrong decisions increases in uncertain times due to lack of complete information (McDonald and Siegel, 1986; Pindyck, 1988). Banks might follow a wait-and-see approach, increase the credit spread, and supply less credit until uncertainty falls down. If the limited amount of lending targets creditworthy borrowers in such times, then banks' stability might improve (Wu et al., 2020). On the other hand, in times of greater uncertainty, the probability of borrowers' default increases, particularly for the firms facing financial constraints (Baum and Wan, 2010; Tang and Yan, 2010). This leads to higher loan losses or declines in bank asset values, translating into deterioration in banks' risk profiles. Besides, firms or households might postpone their investments or spending until uncertainty lessens (Dixit and Pindyck, 1994), which induces a downward pressure on the loan interest rates due to lower credit demand (Hartzmark, 2016). Meanwhile, due to the increased exposure of banks to adverse shocks, depositors demand higher deposit rates (Valencia, 2017). The downward pressure on loan rates and upward pressure on deposit rates jointly reduce the interest rate spreads, the primary profit source for banks. The decrease in profitability can increase moral incentives for banks to search for yield and take on more risk. They might be more willing to engage in "high-risk, highreturn" projects in uncertain times to maintain former profit levels (Rajan, 2006; Dell'Ariccia et al., 2014).

In this paper, we use bank-level data for the US banking industry and assess whether economic policy uncertainty has a role in explaining bank risk post-2007-2008 global financial crisis period, controlling for variables that range from the standard macroeconomic indicators to demand side variables, changes in consumer sentiment, and considering the COVID-19 crisis. To address this, we use the economic policy uncertainty (EPU) index developed by Baker et al. (2016), which uses a text-mining approach to capture policy uncertainty apparent in the newspaper articles and other sources, and considers both short-term and long-term uncertainty

\footnotetext{
3 In 2020, four banks failed, but there are concerns that failures might rise in the future. See https://www.depositaccounts.com/blog/bank-failures/. Most banks that were affected from the 2007-2008 global financial crisis have generally failed in 2010, i.e., two years after the peak. For instance, the number of bank failures in 2008, 2009, and 2010 were 25,140, and 157, respectively.
} 
concerns ${ }^{4}$. As depicted in Figure A2, the EPU index for the US sharply increases during the 2011 debt-ceiling dispute, before the tight presidential elections in 2016, during the COVID-19 crisis, and other main fights over fiscal policy. However, Figure A2 Panels A and B show that real GDP growth and the federal funds rate in the US have been quite stable over the period from 2011 to 2020, except during the COVID-19 crisis period. Bordo et al. (2016) document that EPU has been higher in the recovery period post-2007-2008 global financial crisis as compared to prior recessions. Consistent with Baker et al. (2016), who claim that EPU has a separate influence on the economy, we expect an increase in EPU to deteriorate bank stability.

Next, to gain more insights, we examine the cross-sectional heterogeneity in banks. We investigate whether there is any variation in the relationship between EPU and bank risk for different bank balance sheet conditions. The influence of EPU on bank stability may reflect demand-side effects (i.e., decrease in customer loan demand and borrower distress) as well as supply-side effects (i.e., risk-taking behavior of banks). In this paper, we aim to show that our findings do not entirely originate from customer behavior but are also driven by a change in bank behavior. For this purpose, in our analyses, we control for various demand-side variables, such as the state level Tobin's Q standard investment predictor and firms' cash flows. Such proxies allow isolating demand-driven changes in bank risk to focus on supply effects. We also include quarter and state fixed effects to capture time- and region-specific demand-side shocks that might influence the stability of banks differently. Controlling for such effects, in line with Bordo et al. (2016), we also investigate whether the impact of EPU varies depending on some important bank characteristics such as size, capitalization, liquidity, which would then reflect changes in bank behavior. We focus on these aspects because they have a high priority in Basel accords and policymakers' agendas. Banks have been under more regulatory scrutiny post2007-2008 global financial crisis regarding their size and complexity, and capitalization and liquidity levels which would potentially have influenced their risk-taking behaviors under policy uncertainty.

Regarding the potential influence of size, the US banking sector has been considerably more concentrated since the 1990s, with a small group of the largest banks holding significantly more shares of assets ${ }^{5}$. With the Dodd-Frank Act and Basel III, larger and systemically important financial institutions have been subject to additional regulations mainly in terms of capital and liquidity. The largest financial institutions objected to these new standards fearing a decrease in their profitability and efficiency, and lower synergies not enabling them to deliver services at a lower cost. There is a view in the literature that larger banks have lower risk exposure than smaller institutions because of their higher managerial capacity and efficiency (Boyd and Prescott, 1986; Salas and Saurina, 2002). They could also benefit from better corporate governance practices and face more reputational risks than smaller banks, inducing them to take less risk (Bhagat et al., 2015). However, it is generally believed that because they are considered as too big to fail and expect to benefit from government support and bailout, larger banks have incentives for excessive risk-taking both in normal and uncertain times. They tend to amplify their risk-taking and create competitive distortions (Uhde and Heimeshoff, 2009; De Jonghe, 2010; Bhagat et al., 2015). Indeed, in policy uncertain times, the dual presence of government-

\footnotetext{
${ }^{4}$ The index aims to capture uncertainty related to “...who will make economic policy decisions, what economic policy actions will be undertaken and when, and the economic effects of policy actions (or inaction) - including uncertainties related to the economic ramifications of "non-economic" policy matters, e.g., military actions" (Baker et al. 2016, p.5).

${ }^{5}$ The 5-Bank Asset Concentration for the US has increased from 29\% in 1996 up to $46 \%$ in 2010. Since 2010, it has stayed relatively stable, 46\% again in 2017 (Global Financial Development Database (GFDD), The World Bank.)
} 
induced economic policy ambiguity and additional regulations might have increased the pressure on larger banks to maintain their profitability levels. As such, they might have engaged more in "high-risk, high-return" projects and might have taken excessive risks (Rajan, 2006; Dell'Ariccia et al., 2014). In line with this view, we expect to find that economic policy uncertainty would negatively impact the stability of larger banks to a greater extent.

Regarding the effect of bank capital, banks have been under tighter capital requirements as reflected in the Basel III Accords after the 2007-2008 global financial crisis. Higher capitalization and hence higher franchise value are expected to reduce risk-taking incentives since shareholders have more to lose in case of failure with higher bankruptcy costs (Keeley, 1990; Keeley and Furlong, 1990; Bordo et al., 2016). On the one hand, higher levels of capital might intensify bank risk in uncertain times. This could be because a decrease in leverage (increase in capital) might exacerbate agency problems between managers and shareholders, the latter encouraging the former to take on more risk. Since they are more confident because banks are holding more capital, debt holders could also decrease the pressure on banks to perform efficiently, increasing banks' incentives for excessive risk-taking (Jensen and Meckling, 1976; Diamond and Rajan, 2001). On the other hand, when banks hold more capital, they tend to conduct a more intensive screening of borrowers and monitor them closely, reducing the probability of default (Coval and Thakor, 2005; Mehran and Thakor, 2011). Besides, when there is more capital, the moral hazard problems related to asset substitution are lessened, and banks decrease the level of risky projects (Berger and Bouwman, 2013). The riskshifting incentives of shareholders towards riskier projects are diminished since they have more to lose. Empirical studies generally tend to support the view that higher capital levels improve bank stability, especially during crisis times when uncertainty is amplified (see Demirguc-Kunt et al., 2013; Berger and Bouwman, 2013). Thus, in line with this view, we expect that higher capitalization would have helped to alleviate the negative consequences of economic policy uncertainty on bank stability.

Regarding bank liquidity, during the Great Recession, many financial institutions that were well-capitalized but mainly reliant on short-term wholesale funding faced severe liquidity shortages. Banks that relied more on stable funding sources (such as core deposits) faced less severe problems and continued lending (Cornett et al., 2011). Accordingly, macroprudential supervision post-2007-2008 global financial crisis has focused not only on banks' capital adequacy but also on their liquidity levels (DeYoung et al., 2018). On the one hand, too much liquidity might increase bank risk in uncertain times. This is because when banks hold higher portions of liquid assets, they might disregard downside risk and underprice the risk of projects, which might lead to lax lending standards, propagate excessive lending and increase default risk (Acharya and Naqvi, 2012). This is because, holding a higher share of liquid assets, banks anticipate a lax audit policy and assign less weight to the scenario that they might face liquidity shortfalls. They, in turn, have a tendency to increase their loan volume and underestimate credit risk. On the other hand, as experienced in the 2007-2008 global financial crisis, higher liquidity would be expected to improve bank stability in uncertain times because it creates a buffer that ensures against urgent withdrawal needs and the fire sale of assets. It avoids the cost of raising external finance in the case of liquidity shortfalls and thus improves the soundness of the banking sector, especially during crisis times (see Berger and Bouwman, 2009; Acharya and Naqvi, 2012; Bonner et al. 2015; among others). In line with the second view, in our analysis, we expect to find that the increase in bank risk in policy uncertain times would be mitigated for banks with higher liquidity. 
Using a sample of 5656 US commercial banks and 189,566 quarterly observations over the period from 2011Q1 to 2020Q3, our findings indicate that higher economic policy uncertainty is significantly associated with an increase in bank risk. The results are robust to alternative bank risk and economic policy uncertainty measures, controlling for standard macro-economic variables, demand-side factors as well as the COVID-19 crisis, changes in consumer sentiment, and for bank size classes. We also address endogeneity concerns by conducting two-stage least squares (2SLS) estimations with instrumental variables. We follow Gulen and Ion (2016) and Berger et al. (2020) and use the Senate polarization index as an instrument for $E P U$ and confirm our baseline findings. For deeper insights, we also decompose our primary bank stability measure, the Z-score, into its two components, i.e., risk-adjusted returns and risk-adjusted capitalization. Our findings show that bank stability decreases in times of higher EPU in the US due to falls in both risk-adjusted returns and risk-adjusted capitalization.

We find that after the global financial crisis of 2007-2008, economic policy uncertainty has significantly and negatively affected bank stability in the US, possibly explaining the weak recovery and volatility in bank stability thereafter. Such findings could also have implications for Europe because the EPU index has risen more in most European countries than the index for the US after the crisis and European financial systems are more bank dependent. Our findings also have implications for managing crises times like the COVID-19 pandemic, because proactive economic policies and reduction of policy ambiguity play a critical role during such unusual times to ensure that the stability of banking system is not further negatively affected. Controlling for state-level demand-side variables such as investment opportunities and firm growth in the corresponding states, and including time and state-fixed effects to capture the differences regarding region and time specific demand side shocks, we show that the decrease in bank stability is associated with bank financial characteristics. Specifically, we document that higher economic policy uncertainty is associated with higher bank risk at larger banks, weakly capitalized, and less liquid banks. This shows that our findings not only originate from the demand-side responses but also reflect a change in bank choices. We also provide supportive evidence regarding the Basel III initiatives aimed at raising the capital levels of financial institutions with more stringent rules for the larger banks, and in terms of the introduction of the new liquidity rules.

The rest of the paper is organized as follows. Section 2 presents our data and variables, and Section 3 presents our empirical specification and results. Section 4 concludes the paper and provides policy implications.

\section{Data and Variables}

To investigate the relationship between EPU and bank stability, we collect data from various sources. The data on bank-level variables are extracted from the Fitch Connect database; economic policy uncertainty data is taken from Baker et al. (2016); macroeconomic variables are from the Federal Reserve Bank of St. Louis; demand controls are from Compustat. This section provides the details on the data collection, variable generation, and summary statistics. A brief description of variables and data sources are provided in Table 1. 
We extract bank-level data from the Fitch Connect database ${ }^{6}$, initially for a quarterly panel of 6088 US commercial banks from 2011Q1 to 2020Q3 ${ }^{7}$. We focus only on commercial banks to minimize any bias due to business model differences among banks (Bordo et al., 2016; Berger et al., 2020). To mitigate potential selection bias issues, we include all banks in the database, including those that have ceased operations. We consider consolidated data only to prevent double counting banks reporting both at consolidated and unconsolidated levels. Next, we delete banks with less than three subsequent quarters of time series observations, as our bank stability measure (ZSCORE) is calculated over three quarter rolling windows (Beck et al., 2013). The final sample is a panel of 5654 banks and 189,566 quarterly observations. We winsorize all bank-level variables at the $1 \%$ and $99 \%$ levels to deal with outliers.

\section{$>><$ INSERT TABLE 1 AROUND HERE $<<<$}

\subsection{Bank stability indicators}

Our main bank stability measure as a dependent variable is the Z-score, a widely used measure of bank stability in the banking literature (Lepetit et al., 2008; Laeven and Levine, 2009; Beck et al., 2013, among others). It is calculated as:

$Z_{i t}=\frac{E Q T A_{i t}+R O A_{i t}}{S D R O A_{i t}}$

where $\mathrm{i}$ and $\mathrm{t}$ denote bank and quarter, respectively. EQTA indicates the ratio of equity to total assets. ROA shows return on assets, and SD ROA is the standard deviation of ROA calculated using 3-quarter rolling windows instead of using the entire sample period to allow for timevariation in the denominator (Beck et al., 2013). The Z-score is interpreted as the inverse of the probability of failure with higher values indicating more stability. It is the number of standard deviations by which bank returns have to fall to wipe out all equity in a bank. Since Z-score is highly skewed, we follow the literature and take the natural logarithm of the index (Laeven and Levine, 2009; Beck et al., 2013) and call this variable ZSCORE. Table 2 reveals that ZSCORE has an average of 2.50 with a substantial standard deviation of 1.24.

To better understand how EPU affects bank stability, we decompose the Z-score into its two components (Lepetit et al., 2008; Barry et al., 2011; Danisman and Tarazi, 2020), risk-adjusted capitalization (ZSCORE1) and risk-adjusted profitability (ZSCORE2). ZSCORE1 is calculated as the natural logarithm of the first component EQTA / SD ROA, and ZSCORE2 is taken as the natural logarithm of the second component ROA/SD ROA.

To check for robustness, we also use alternative bank risk indicators such as non-performing loans to gross loans ratio $(N P L)$ and the share of loan loss provisions in gross loans (LLP). Moreover, we alternatively calculate the Z-score using 5-quarter rolling windows for SD ROA, take its natural logarithm and denote this variable as ZSCORE5.

\section{$>><$ INSERT TABLE 2 AROUND HERE $<<<$}

\footnotetext{
${ }^{6}$ Fitch Connect is a database compiled by Fitch Solutions and contains comprehensive bank level information. When Fitch stopped working with Bureau van Dijk (BvD) and BankScope was ceased in 2016, Fitch Connect was created as an alternative.

${ }^{7}$ The sample period starts with the year 2011 because older data is not available in the database.
} 


\subsection{Economic policy uncertainty measures}

We use economic policy uncertainty indices which are developed by Baker et al. $(2016)^{8}$. We use the composite EPU index in our baseline estimations, which is the most comprehensive policy uncertainty measure for the US in their database. It captures general economic policy uncertainty in the newspaper articles ${ }^{9}$ and the uncertainty related to government spending, inflation risk, and tax code expirations from other sources ${ }^{10}$. Baker et al. (2016) use a textmining approach to capture policy uncertainty and consider both short-term and long-term uncertainty concerns. The index is available monthly in the database, and we use the quarterend values to generate our main quarterly variable for the period ranging from 2011Q1 to 2020Q3. We follow Gulen and Ion (2016) and Berger et al. (2020) and take the natural logarithm of the index because it is highly skewed, and we call the transformed variable $E P U$ for brevity. Table 2 presents the descriptive statistics and shows that $E P U$ ranges from 4.38 to 5.65 with an average of 4.88 and a standard deviation of 0.31 , indicating considerable variation across quarters.

For robustness, we also use alternative definitions of this variable. Instead of quarter-end values we take the average of the three months of the corresponding quarter and then its natural logarithm EPU V2. We also use a component of the composite index available in Baker et al. (2016) database, news-based uncertainty, capturing the policy uncertainty only in newspaper articles. We use the quarter-end values of this variable and then take its natural logarithm and call it EPU NEWS.

\subsection{Bank level controls}

Following the bank stability literature, we control for numerous bank-level indicators (Lepetit et al., 2008; Houston et al., 2010; Beck et al., 2013; Berger et al., 2017; Danisman and Demirel, 2019).

We first control for differences in bank size (SIZE) and calculate it as the natural logarithm of total assets ${ }^{11}$. We take the natural logarithm because the variable is highly skewed. On the one hand, larger banks are likely to have higher incentives for risk-taking because they are considered as "too big to fail" (Uhde and Heimeshoff, 2009; De Jonghe, 2010; Bhagat et al., 2015). On the other hand, larger banks are expected to have more diversified loan portfolios and hence to be less exposed to borrowers' default (see Diamond, 1984; Boyd and Prescott, 1986). They are also likely to have better corporate governance and face more reputational risks

\footnotetext{
${ }^{8}$ The indices are downloaded from https://www.policyuncertainty.com and more information on the indices is available in Baker et al. (2016).

${ }^{9}$ The newspaper-based uncertainty component is constructed by counting the frequency of articles in 10 major US newspapers that include the following triple: "economic" or "economy"; "uncertain" or "uncertainty"; and one or more of "congress", "deficit", "Federal Reserve", "legislation", "regulation" or "White House". It is based on ten major newspapers in the US: the Boston Globe, the Chicago Tribune, the Los Angeles Times, the New York Times, the Wall Street Journal, the Washington Post, Dallas Morning News, the Miami Herald, the San Francisco Chronicle and USA Today.

${ }^{10}$ Uncertainty regarding the tax code expirations is extracted from the reports by the Congressional Budget Office (CBO). Temporary tax measures create uncertainty for businesses and households because Congress usually extends them unnoticed. Uncertainty related to government spending; inflation risk draws on the Federal Reserve Bank of Philadelphia's Survey of Professional Forecasters. They take into account the dispersion in the individuallevel data for CPI, purchases of goods and services by state and local governments, and purchases of goods and services by the federal government. Government policy is expected to have a direct impact on the dispersion in these variables.

${ }^{11}$ We use constant 2018 US dollars to remove the effect of inflation. SIZE is the only variable that enters the regression in levels and the rest of the variables are ratios.
} 
than smaller banks, which might induce them to take less risk (Boyd and Prescott, 1986; Salas and Saurina, 2002). We next control for liquidity differences by including the ratio of liquid assets to total assets (LIQTA). As part of their overall strategy, banks hold cash and other liquid assets to manage their liquidity risk. While higher liquidity holdings may reduce overall bank portfolio risk because such holdings are safer than longer-term loans, especially in crisis times (Cornett et al. 2011), too much liquidity might encourage banks to disregard downside risk and underprice the risk of projects, which gives rise to relaxed lending standards and excessive lending (see Acharya and Naqvi, 2012).

We also control for differences in banks' operational efficiency by using the operating cost to operating income ratio $(C I R)$. CIR serves as an indicator of management's ability to control costs, and higher $C I R$ is expected to increase default risk. According to the bad management hypothesis, poor skills in terms of credit scoring, monitoring borrowers, and evaluation of pledged collaterals might lead to improper risk management (Louzis et al., 2012; Poghosyan and Cihak, 2011). We next control for asset growth by including the growth of total assets (GTA). The impact of higher growth on bank stability is ambiguous because while it could be one of the first drivers of bank risk, it might also bring more stability due to improvements in overall business conditions. Finally, we control bank diversification by considering the ratio of non-interest income to gross revenues (NII). Most studies find that banks expanding more into non-interest income activities generally show higher insolvency risk because of relatively high correlation across different business lines and specifically between traditional lending activities and commission and fee activities as well as trading activities (see Lepetit et al. 2008; Köhler, 2014; Chen et al., 2017; DeYoung and Torna, 2013; Williams, 2016; among others).

\subsection{Macro-economic and demand-side controls}

To properly isolate the effect of EPU from the influence of other macro-economic variables, we use several macro-economic controls in our models. We select the variables mainly following Bordo et al. (2016), Gulen and Ion (2016), and Berger et al. (2020). We use the quarterly real GDP growth rate $(R G D P G R W)$ and the quarterly percentage change in the federal funds rate (FED FUNDS RATE). We also use the quarterly percentage change in the forwardlooking expectations index of consumer sentiment from the University of Michigan (CONS $S E N T$ ) to control for the expected economic outlook. An increase in CONS SENT shows more optimistic consumer expectations and is expected to be associated with higher bank stability. The macro-economic variables and CONS SENT are extracted from the website of The Federal Reserve Bank of St. Louis. Our analysis period includes the COVID-19 pandemic period, and we need to control its potential impact on bank stability. For this purpose, we generate an indicator variable, COVID19, that equals 1 for the quarters 2020 Q2 and 2020 Q3 and 0 otherwise $^{12}$.

To ensure that our findings reflect a change in bank choices rather than just demand-side responses, we control for some demand-side factors, following mainly Gulen and Ion (2016) and Berger et al. (2020). Since corporate investment is a crucial indicator of the demand for banking services, we control for classic investment predictors at the state level, such as Tobin's $\mathrm{Q}$ and cash flows, taking the data from Compustat. First, we control for cash flows (CASH

\footnotetext{
${ }^{12}$ It might be the case that the severe effects of COVID-19 on financial institutions and the real economy have started being observed in 2020 Q1. To account for this, we use an alternative definition of the COVID19 variable. We generate the variable as such that it equals to 1 for 2020Q1, 2020 Q2 and 2020 Q3; and 0 otherwise. Our findings are consistent with this alternative definition and available upon request.
} 
FLOWS), generated as a quarterly state-level variable taken as the ratio of the cross-sectional average of operating cash flows to the lagged total assets for each firm located in the corresponding state. Higher values of CASH FLOWS indicate more investment opportunities for the firms in the corresponding states (Gulen and Ion, 2016). We expect to find a positive association between CASH FLOWS and demand for banking services which would induce a positive impact on bank stability. Second, we include Tobin's Q (TOBINS Q), which is constructed as a quarterly state-level variable calculated as the ratio of the cross-sectional average of Tobin's $\mathrm{Q}$ for each firm located in the corresponding state. TOBINS $Q$ is defined as the ratio of the market value of assets to the book value of assets and is another standard indicator of investment opportunities with higher values showing the attractiveness of investment in the corresponding state, implying more demand for banking facilities. Table 2 indicates that the average of TOBINS $Q$ of firms across states is 2.04 and the average of $C A S H$ FLOWS of firms is $0.02^{13}$.

Table A1 shows correlation coefficients between the variables and indicates no major collinearity problems.

\section{Empirical Specification and Results}

In this section, we first present our empirical specification and then the findings.

\subsection{Empirical Specification}

Our baseline specification to test the effects of EPU on bank stability is as follows:

$\operatorname{ZSCORE}_{i t}=\beta E P U_{t-1}+\theta^{\prime} X_{i, t-1}+\vartheta^{\prime} Y_{t-1}+\mu^{\prime} Z_{i, t-1}+\alpha_{i}+\mu_{t}+\varepsilon_{i t}$

where i stands for individual banks and t stands for quarters. The dependent variable is the Zscore (ZSCORE), and our key independent variable is the economic policy uncertainty index $(E P U)$. X stands for bank-level control variables, Y for macroeconomic controls, and $\mathrm{Z}$ represents demand-side variables. We use the first-lag of the independent variables to mitigate any potential reverse causality issues. We estimate our regressions using panel data estimation techniques for a panel of 5654 US commercial banks for the period 2011Q1 to 2020Q3, use bank fixed effects to account for variation between banks, and include quarter dummies to account for seasonality. We cluster the standard errors at the bank level to correct for withinbank correlation.

Next, to examine cross-sectional bank heterogeneity, we investigate whether there is any variation in the relationship related to different bank balance sheet conditions using the following model:

$$
\begin{aligned}
& Z S C O R E_{i t}=\beta_{1} E P U_{t-1}+\beta_{2}\left(E P U_{t-1} * M_{i, t-1}\right)+\beta_{3} M_{i, t-1}+\theta^{\prime} X_{i, t-1}+\vartheta^{\prime} Y_{t-1}+\mu^{\prime} Z_{i, t-1}+ \\
& \alpha_{i}+\mu_{t}+\varepsilon_{i t}
\end{aligned}
$$

M stands for the bank-level balance sheet conditions that are bank size (SIZE), capitalization (EQTA), and liquidity (LQTA).

\footnotetext{
${ }^{13}$ The averages of TOBINS $Q$ and CASH FLOWS are similar in magnitude with the studies of Berger et al. (2020) and Gulen and Ion (2016). The average of TOBINS $Q$ is also comparable with the average values of these variables for the Compustat universe presented in Bertrand and Schoar (2003) for the 1969-1999 period.
} 


\subsection{Results}

In this section, we first present the findings of our baseline estimations, our instrumental variable analysis as well as robustness checks. We then report the results of the bank-level heterogeneity analysis.

\subsubsection{Baseline Results}

Table 3 presents the regression results of $E P U$ on bank stability. We implement panel data estimation techniques and use bank and quarter fixed effects unless otherwise stated. The first lags of all explanatory variables are included to mitigate any potential reverse causality. Standard errors are clustered at the bank level and given in parentheses. Columns 1-4 use ZSCORE as dependent variables. Column 1 includes the bank controls (X) and macro-economic controls (Y) in the regression. CONS SENT is added in Column 2, and demand controls (Z) are included in Column 3, respectively. Column 4 contains all explanatory variables but uses state fixed-effects as an additional control for demand-side effects. We observe that, in all these specifications, the coefficient of EPU is significant and negative at the $1 \%$ level, indicating that economic policy uncertainty is significantly associated with a decrease in bank stability. The coefficient of the EPU term falls (in absolute value) gradually as we add more variables in the regressions in Columns 2-4, but always still stays significant. The finding is robust after controlling for standard macroeconomic variables, changes in the consumer sentiment, and demand-side indicators consistent with influencing both bank behavior (supply-side) and customer behavior (demand-side).

In terms of economic magnitude, Column $3^{14}$ shows that a one-standard-deviation increase (0.31) in EPU leads to a decrease in ZSCORE by $15.08 \%$ relative to its mean value. To deepen our understanding of how EPU affects bank stability, we decompose the Z-score into its components in Columns 5\&6 and use ZSCORE1 and ZSCORE2 as dependent variables, respectively. The results in Columns 5 and 6 show that an increase in EPU is significantly associated with a decrease in both risk-adjusted capitalization (ZSCORE1) and risk-adjusted profitability (ZSCORE2), with the absolute value of the coefficient of ZSCORE1 being higher in magnitude. Specifically, a one-standard-deviation increase (0.31) in EPU leads to a decrease in ZSCORE1 by $49.4 \%$ and a reduction in ZSCORE2 by $11.14 \%$ relative to their mean values. While both economically significant, the negative impact of $E P U$ on risk-adjusted capitalization is relatively higher.

The coefficients of the control variables are generally consistent with expectations. The coefficients of $N I I$ and $C I R$ are negative and significant indicating that more diversified banks and less efficient banks show higher default risk. Banks with higher asset growth (GTA) are more stable in line with the stabilizing impact of asset growth opportunities. Banks with higher liquidity (LIQTA) are observed to be less stable, but the significance of the relationship is relatively weak at a level of $10 \%$. Concerning macro controls, we observe that banks are less stable in times of higher GDP growth. During higher growth periods borrowers default less and hence we could expect a positive relationship between growth and bank stability. Nevertheless, because they are more confident about economic prospects, banks might also have a tendency to take on more risk (Buch et al. 2014). Our sample period covers the recovery period subsequent to the great recession with smooth economic conditions and a low interest

\footnotetext{
${ }^{14}$ For the rest of the estimations, we will use Column 3 as our main specification.
} 
rate environment. Our results are hence consistent with the risk-taking channel and search for yield behavior of banks (Crocket, 2002; Acharya and Naqvi, 2012; Shim, 2013). An increase in the federal funds rate is associated with higher bank stability. This is in line with the recent strand of literature that documents how bank risk is propagated in low-interest-rate environments (Agur and Demertzis, 2012; Delis and Kouretas, 2011). An increase in consumer sentiment that shows more optimistic consumer expectations is associated with higher bank stability. The coefficient of the COVID19 term is negative and significant, revealing the negative impact of the pandemic on bank stability. Looking at the demand-side controls, we see that, as expected, banks in states with firms that have higher cash flows and higher Tobin's $Q$ are more stable.

Overall, we find that in times of higher EPU, bank stability decreases mainly due to a decrease in both risk-adjusted capitalization and risk-adjusted profitability. This supports the view that the risk-adjusted capitalization levels of banks are reduced in uncertain times due to an increase in their lending to riskier borrowers (Maddaloni and Peydró, 2011; Dell'Ariccia et al., 2012). Simultaneously, the bank shareholders' return target does not adjust immediately in uncertain times, leading banks to search for yield. Banks have more incentives to engage in "high-risk, high-return" projects, increasing the volatility of their profits and increasing their risk levels (Rajan, 2006; Dell'Ariccia et al., 2014).

\section{$>><$ INSERT TABLE 3 AROUND HERE $<<<$}

\subsubsection{Instrumental variable analysis}

This section performs an alternative estimation technique, instrumental variable (IV) two-stage least squares analysis (2SLS), which mitigates any potential endogeneity. Endogeneity can be an issue because, despite we use a wide range of control variables, some omitted variables such as overall uncertainty in the economy might affect both EPU and bank stability. Simultaneously, even though this is less likely to occur, an increase in overall bank risk might create regulatory uncertainty for the policymakers, generating reverse causality issues. A good instrument is expected to be significantly related to policy uncertainty and influence bank stability only through this link. We follow Gulen and Ion (2016) and Berger et al. (2020) and use the Senate polarization index (POLARIZ) as an instrument for $E P U^{1516}$. This index is based on the DW-NOMINATE scores of McCarty et al. (1997), which tracks legislators' ideological positions on government intervention in the economy over time. We use the first dimension of DWNOMINATE scores, which refers to socio-economic matters (Poole and Rosentahl, 2000). It is calculated as the difference between the average scores for the Republican party members and Democratic party members in the Senate. An increase in partisan polarization can bring policy gridlock that retards legislative coalitions and generates policy uncertainty (McCarty, 2012). Therefore, our instrument satisfies the relevance condition. However, it is not directly

\footnotetext{
${ }^{15}$ The senate polarization index is downloaded from https://www.voteview.com/data.

${ }^{16}$ Attig et al. (2021) provide a summary table of recent EPU studies that address endogeneity using IV estimations and among ten such studies, six of them use political polarization as an instrument. Other studies mainly use partisan conflict index of Azzimonti (2018) and migration fear index (Bonaime et al., 2018; Matousek et al., 2020). In our IV estimation, we have also tried using partisan conflict index of Azzimonti and migration fear index from the Economic Policy Uncertainty website (http://www.policyuncertainty.com/immigration_fear.html). Our findings continue to hold when we use them as alternative instruments and the results are available upon request.
} 
evident why the level of disagreement between politicians would be directly correlated to bank stability, meeting the exclusion restriction.

Table 4 replicates our baseline findings using POLARIZ as an instrument for EPU. Both EPU and POLARIZ are cross-sectionally invariant i.e., their values are the same for each bank within a quarter. Therefore, Gulen and Ion (2016) state that the regular 2SLS is inappropriate because it would overestimate the correlation between EPU and its instrument. We follow their approach and conduct time-series regression in the first stage and panel data estimation in the second stage. The standard errors in the first stage are adjusted for autocorrelation using the Newey and West (1987) procedure with 12 lags. First stage estimation results are presented in Column 1, and we observe the expected positive and significant effect of POLARIZ on EPU. We test and confirm the relevance of the instrument using the F-statistic for the instrumental variable, which is 16.29 and significant at the $1 \%$ level $^{17}$, well above the weak instrument criteria (Stock and Yogo, 2005). Columns 2-4 show the second stage regressions results for the dependent variables ZSCORE, ZSCORE1, and ZSCORE2, respectively. The coefficient of $\widehat{E P U}$ keeps its negative sign and significance, confirming our baseline findings.

\section{$>><$ INSERT TABLE 4 AROUND HERE $<<<$}

\subsubsection{Robustness Checks}

We perform robustness checks for the baseline findings, and we present them in Table 5 . Columns 1 and 2 use alternative economic policy uncertainty indicators, EPU NEWS and EPU $V 2$. We observe that the coefficients of the alternative uncertainty measures are all negative and significant at the $1 \%$ level, confirming our baseline findings.

Next, in the following three columns of Table 5 (Columns 3-5), we use alternative bank stability measures, namely non-performing loans to gross loans ratio $(N P L)$, the share of loan loss provisions in gross loans $(L L P)$, and an alternative the default risk measure ZSCORE 5. We see that the coefficients of $E P U$ are positive and significant at the $1 \%$ level for Columns $4 \& 5$, showing that an increase in EPU is positively associated with higher levels of non-performing loans and loan loss provisions, decreasing bank stability. For deeper insights, we use SD ROA and $R O A$ as dependent variables in Columns $6 \& 7$. We observe that the coefficient of $E P U$ is positive and significant at the $1 \%$ level for SD ROA, but not statistically significant for ROA. This shows that economic policy uncertainty increases bank risk by increasing the volatility of profits, but it does not have significant impact on profitability.

\section{$>><$ INSERT TABLE 5 AROUND HERE $<<<$}

\subsubsection{Heterogeneity analysis}

In this section we conduct bank-level heterogeneity analysis to identify the possible channels through which EPU impacts bank stability. Potential channels we explore are bank size, capital, and liquidity.

\footnotetext{
${ }^{17}$ Rejects the null hypothesis that the instrument is not exogenous.
} 


\subsubsection{Differences in bank size}

First, we explore the influence of size, and our findings are displayed in Table 6. We use ZSCORE as the dependent variable in all columns. In Column 1, the interaction term between $E P U$ and SIZE appears positive and significant, showing that the negative influence of economic policy uncertainty on bank stability is greater in magnitude for larger banks. For robustness, in Column 2, we create SIZE terciles and interact these variables with EPU. We see that these interaction terms are significant and positive for both second tercile and third tercile, and the magnitude of the coefficient is larger for the third tercile term. This confirms our finding that higher EPU decreases stability more for banks of larger size. As a second robustness check, we follow Abedifar et al. (2018) and classify banks as Small if their total assets are less than $\$ 100$ million; as Medium if their total assets are between $\$ 100$ million and \$1 billion, as Large if their total assets are more than $\$ 1$ billion and as GSIBS if their total assets are more than $\$ 50$ billion. We present the findings in Columns 3-6, which reveal that even though EPU decreases bank stability for all subsamples, the impact is highest for Large and GSIBS banks.

Overall, we observe that the negative impact of EPU on bank stability is more severe for larger banks. This could be explained by the fact that policy uncertainty post-2007-2008 global financial crisis might have created additional incentives for larger banks to maintain their profitability levels and might have induced them to engage in "high-risk, high-return" projects, increasing their risk (Rajan, 2006; Dell'Ariccia et al. 2014) ${ }^{18}$. Larger banks also know that they might benefit from being too-big-to fail and hold riskier loan portfolios in uncertain times (Uhde and Heimeshoff, 2009; De Jonghe, 2010; Kane, 2010). Another explanation is that larger banks tend to be more geographically diversified than smaller banks, and they might aim to generate more profit overseas when there is national uncertainty which might increase their risks (Bordo et al. 2016).

\section{$>><$ INSERT TABLE 6 AROUND HERE $<<<$}

\subsubsection{Differences in capital levels}

Next, we investigate in Table 7 whether the relationship between EPU and bank stability changes for banks with higher capital levels. In Column 1, the interaction term between EPU and EQTA appears positive and significant, revealing that the negative influence of economic policy uncertainty on bank stability decreases for banks with higher capital levels. As a robustness check, we construct EQTA terciles and evaluate the interaction of EQTA terciles with EPU in Column 2. We see that the increase in bank stability is observed for the second and third EQTA tercile for the banks with the largest capital ratios. Columns 3 and 4 divide the sample into two subsamples, indicated as EQTA LOW (EQTA<median) and EQTA HIGH (EQTA>median), respectively. We observe that the coefficient of EPU is higher in magnitude for the EQTA LOW subsample, confirming that the negative impact of EPU on bank risk is larger for weakly capitalized banks. This is in line with the franchise value risk-taking mitigating effect. Indeed, in the presence of bankruptcy costs, when there is more capital at stake, shareholders have more to lose in case of bankruptcy (Keeley, 1990; Keeley and Furlong, 1990). Columns 5 and 6 use alternative capital ratios for robustness, TIER1, and REGCAP where TIER 1 stands for the ratio of core tier 1 capital to the total risk-weighted assets and $R E G$

\footnotetext{
${ }^{18}$ To gain more insights on possible higher risk-taking incentives for large banks we also run the regressions using SD ROA as a dependent variable. EPU turns out to be more strongly linked (higher significant coefficient value) with the volatility of profitability for larger banks. The results are available upon request.
} 
$C A P$ indicates the ratio of total regulatory capital ratio (the sum of tier 1 and tier 2 capital) to the total risk-weighted assets. EPU keeps its negative and significant coefficient in line with previous findings.

\section{$>><$ INSERT TABLE 7 AROUND HERE $<<<$}

Overall, we find that the decrease in bank stability is mitigated for strongly capitalized banks under policy uncertainty and that capital provides a cushion. This is consistent with the positive capital buffer effect and the reduced risk-taking incentives resulting from higher capitalization (Keeley, 1990; Keeley and Furlong, 1990; Bordo et al., 2016). Higher capital levels increase bank's incentives to monitor borrowers, which reduces the probability of default (Coval and Thakor, 2005; Mehran and Thakor, 2011). And higher capital weakens asset substitution moral hazard, leading banks to decrease their level of innovative but risky products that would elevate the negative consequences of uncertainty (Berger and Bouwman, 2013).

\subsubsection{Differences in liquidity levels}

Table 8 investigates the bank-level differences in the liquidity levels. Column 1 shows that the interaction term between EPU and LIQTA ${ }^{19}$ is positive and significant, indicating that the negative association between EPU and bank stability is reduced for banks with higher liquidity. This finding is confirmed in Column 2 when we use LIQTA terciles and interact them with EPU. It is seen that the decrease in bank risk is experienced for the third LIQTA tercile for the banks with the largest liquidity ratio. We divide our sample into two in Columns 3 and 4, LIQTA LOW (LIQTA<median) and LIQTA HIGH (LIQTA>median), respectively. The coefficient of EPU and the negative effect on bank stability is higher in magnitude for the LIQTA LOW subsample, confirming that the negative impact of EPU on bank stability is higher for less liquid banks. Higher liquidity hence appears to serve as a buffer by decreasing the negative impact of EPU on bank stability. Columns 5 incorporates an alternative bank liquidity indicator, DEPLOANS. DEPLOANS stands for the ratio of deposits to net loans whose higher values would indicate higher liquidity. Many studies use the level of deposits received from investors as a share of loans as an indicator of liquidity which is simply the inverse of the loansto- deposits ratio that has long been used by bankers (Acharya and Naqvi, 2012; DeYoung et al., 2018). Columns 5 shows that the interaction term between DEPLOANS and EPU is positive and significant, in line with previous results.

Our findings suggest that higher liquidity levels help to soften the negative impacts of EPU on bank stability. This is in line with the literature that states that higher liquidity creates a buffer and helps banks keep sufficient funds for urgent withdrawal needs and avoids fire sale of assets in uncertain times. Higher liquidity levels avoid the extra cost of external finance and improves the banking sector's soundness, especially during crisis times (see Berger and Bouwman, 2009; Acharya and Naqvi, 2012; Bonner et al. 2015; among others).

\section{$>><$ INSERT TABLE 8 AROUND HERE $<<<$}

\footnotetext{
${ }^{19}$ Liquid assets include "Securities and assets classified as held for trading excluding derivatives + Loans \& Advances $<3$ months + Loans \& Advances to Banks $<3$ months".
} 


\section{Conclusion}

Our findings consistently reveal that higher economic policy uncertainty is significantly associated with a decrease in bank stability originated not only from borrowers' and customers' conditions but also from changes in banks' behavior. The findings are robust to alternative bank risk and economic policy uncertainty measures, controlling for standard macro-economic, demand-side factors, the COVID-19 crisis, changes in consumer sentiment, and for bank size. They also continue to hold when we use an alternative estimation technique, instrumental variable (IV) two-stage least squares analysis (2SLS), that deals with potential endogeneity issues.

We find that in times of higher EPU, bank stability decreases mainly due to a decrease in both risk-adjusted capitalization and risk-adjusted profitability. Deeper investigation shows that higher EPU increases the volatility of bank profitability without affecting its level. We also see that this negative influence of EPU on bank stability is heterogeneous across banks: the stability of banks that are better capitalized or more liquid is less affected than that of other banks. Larger banks are also more affected than smaller banks. Our findings support the Basel III initiatives aimed at raising the capital levels of financial institutions with tighter rules and stricter supervision for the larger ones. They also support the implementation of the newly introduced liquidity rules which were absent from Basel II. Our study also has important implications for managing crises such as the COVID-19 pandemic by showing that, to ensure that bank stability is not further affected, policy makers need to draw a clear and unambiguous line during both the crisis and recovery periods.

\section{References}

Abedifar, P., Molyneux, P., \& Tarazi, A. (2018). Non-interest income and bank lending. Journal of Banking \& Finance, 87, 411-426.

Acharya, V., \& Naqvi, H. (2012). The seeds of a crisis: A theory of bank liquidity and risk taking over the business cycle. Journal of Financial Economics, 106(2), 349-366.

Agur, I., \& Demertzis, M. (2012). Excessive bank risk taking and monetary policy. Working Paper 1457, European Central Bank.

Altunbas, Y., Manganelli, S., Marques-Ibanez, D., 2011. Bank Risk During the Financial Crisis - Do Business Models Matter? ECB Working Paper Series No. 1394. European Central Bank, Frankfurt.

Ashraf, B. N., \& Shen, Y. (2019). Economic policy uncertainty and banks' loan pricing. Journal of Financial Stability, 44, 100695. 
Attig, N., El Ghoul, S., Guedhami, O., \& Zheng, X. (2021). Dividends and economic policy uncertainty: international evidence. Journal of Corporate Finance, 66, 101785.

Azzimonti, M. (2018). Partisan conflict and private investment. Journal of Monetary Economics, 93, 114-131.

Baker, S. R., Bloom, N., Canes-Wrone, B., Davis, S. J., \& Rodden, J. (2014). Why has US policy uncertainty risen since 1960?. American Economic Review, 104(5), 56-60.

Baker, S. R., Bloom, N., \& Davis, S. J. (2016). Measuring economic policy uncertainty. The quarterly journal of economics, 131(4), 1593-1636.

Barry, T. A., Lepetit, L., \& Tarazi, A. (2011). Ownership structure and risk in publicly held and privately owned banks. Journal of Banking \& Finance, 35(5), 1327-1340.

Baum, C. F., \& Wan, C. (2010). Macroeconomic uncertainty and credit default swap spreads. Applied Financial Economics, 20(15), 1163-1171.

Beck, T., De Jonghe, O., \& Schepens, G. (2013). Bank competition and stability: Cross-country heterogeneity. Journal of financial Intermediation, 22(2), 218-244.

Bekaert, G., Hoerova, M., \& Duca, M. L. (2013). Risk, uncertainty and monetary policy. Journal of Monetary Economics, 60(7), 771-788.

Berger, A. N., \& Bouwman, C. H. (2009). Bank liquidity creation. The review of financial studies, 22(9), 3779-3837.

Berger, A. N., \& Bouwman, C. H. (2013). How does capital affect bank performance during financial crises?. Journal of financial economics, 109(1), 146-176.

Berger, A. N., El Ghoul, S., Guedhami, O., \& Roman, R. A. (2017). Internationalization and bank risk. Management Science, 63(7), 2283-2301.

Berger, A. N., Guedhami, O., Kim, H. H., \& Li, X. (2020). Economic policy uncertainty and bank liquidity hoarding. Journal of Financial Intermediation, 100893.

Bertrand, M., \& Schoar, A. (2003). Managing with style: The effect of managers on firm policies. The Quarterly journal of economics, 118(4), 1169-1208.

Bhagat, S., Bolton, B., \& Lu, J. (2015). Size, leverage, and risk-taking of financial institutions. Journal of banking \& finance, 59, 520-537.

Bilgin, M. H., Danisman, G. O., Demir, E., \& Tarazi, A. (2021). Bank credit in uncertain times: Islamic vs. conventional banks. Finance Research Letters, 39, 101563.

Biswas, S., \& Zhai, W. (2021). Economic policy uncertainty and cross-border lending. Journal of Corporate Finance, 67, 101867.

Bonaime, A., Gulen, H., \& Ion, M. (2018). Does policy uncertainty affect mergers and acquisitions?. Journal of Financial Economics, 129(3), 531-558.

Bonner, C., Van Lelyveld, I., \& Zymek, R. (2015). Banks' liquidity buffers and the role of liquidity regulation. Journal of Financial Services Research, 48(3), 215-234.

Bordo, M. D., Duca, J. V., \& Koch, C. (2016). Economic policy uncertainty and the credit channel: Aggregate and bank level US evidence over several decades. Journal of Financial Stability, 26, 90-106. 
Boyd, J. H., \& Prescott, E. C. (1986). Financial intermediary coalitions. Journal of Economic Theory, 38, 211-232.Buch, C. M., Eickmeier, S., \& Prieto, E. (2014). Macroeconomic factors and microlevel bank behavior. Journal of Money, Credit and Banking, 46(4), 715-751.

Cornett, M. M., McNutt, J. J., Strahan, P. E., \& Tehranian, H. (2011). Liquidity risk management and credit supply in the financial crisis. Journal of financial economics, 101(2), 297-312.

Coval, J. D., \& Thakor, A. V. (2005). Financial intermediation as a beliefs-bridge between optimists and pessimists. Journal of Financial Economics, 75(3), 535-569.

Crockett, A. (2002). Market discipline and financial stability. Journal of Banking \& Finance, 26(5), 977-987.

Danisman, G. O., \& Demirel, P. (2019). Bank risk-taking in developed countries: The influence of market power and bank regulations. Journal of International Financial Markets, Institutions and Money, 59, 202-217.

Danisman, G. O., \& Tarazi, A. (2020). Financial inclusion and bank stability: evidence from Europe. The European Journal of Finance, 26(18), 1842-1855.

De Jonghe, O. (2010). Back to the basis on banking? A micro-analysis of banking system stability. Journal of Financial Intermediation, 19, 387-417.

De Jonghe, O., Diepstraten, M., \& Schepens, G. (2015). Banks' size, scope and systemic risk: What role for conflicts of interest? Journal of Banking \& Finance, 61, S3-S13.

DeYoung, R., Distinguin, I., \& Tarazi, A. (2018). The joint regulation of bank liquidity and bank capital. Journal of Financial Intermediation, 34, 32-46.

Delis, M. D., \& Kouretas, G. P. (2011). Interest rates and bank risk-taking. Journal of Banking and Finance, 35, 840-855.

Dell'Ariccia, G., Laeven, L., \& Marquez, R. (2014). Real interest rates, leverage, and bank risktaking. Journal of Economic Theory, 149, 65-99.

Demirguc-Kunt, A., Detragiache, E., \& Merrouche, O. (2013). Bank capital: Lessons from the financial crisis. Journal of Money, Credit and Banking, 45(6), 1147-1164.

Diamond, D. W. (1984). Financial intermediation and delegated monitoring. The review of economic studies, 51(3), 393-414.

Diamond, D. W., \& Rajan, R. G. (2001). Liquidity risk, liquidity creation, and financial fragility: A theory of banking. Journal of political Economy, 109(2), 287-327.

Dixit, A. K., Pindyck, R. S. (1994). Investment under uncertainty. Princeton university press.

Drobetz, W., El Ghoul, S., Guedhami, O., \& Janzen, M. (2018). Policy uncertainty, investment, and the cost of capital. Journal of Financial Stability, 39, 28-45.

Federal Open Market Committee, Minutes of the December (2009) Meeting, available at http://www.federalreserve.gov/monetarypolicy/fomcminutes20091216.htm.

Gulen, H., \& Ion, M. (2016). Policy uncertainty and corporate investment. The Review of Financial Studies, 29(3), 523-564. 
Hartzmark, S. M. (2016). Economic uncertainty and interest rates. The review of asset pricing studies, 6(2), 179-220.

Houston, J. F., Lin, C., Lin, P., \& Ma, Y. (2010). Creditor rights, information sharing, and bank risk taking. Journal of financial Economics, 96(3), 485-512.

Huang, Y. S., Hasan, I., Huang, Y. C., \& Lin, C. Y. (2020). Political Uncertainty and Bank Loan Contracts: Does Government Quality Matter? Journal of Financial Services Research, 129.

$\mathrm{Hu}$, S., \& Gong, D. (2019). Economic policy uncertainty, prudential regulation and bank lending. Finance Research Letters, 29, 373-378.

IMF (International Monetary Fund). (2012). World Economic Outlook: Coping with High Debt and Sluggish Growth.

IMF (International Monetary Fund). (2013). World Economic Outlook, Hopes, Realities, Risks.

Jensen, M. C., \& Meckling, W. H. (1976). Theory of the firm: Managerial behavior, agency costs and ownership structure. Journal of financial economics, 3(4), 305-360.

Julio, B. and Yook, Y. (2012). Political uncertainty and corporate investment cycles. Journal of Finance, 67(1):45-83.

Jurado, K., Ludvigson, S. C., \& Ng, S. (2015). Measuring uncertainty. American Economic Review, 105(3), 1177-1216.

Kane, E. J. (2010). Redefining and containing systemic risk. Atlantic Economic Journal, 38(3), 251-264.

Karadima, M., \& Louri, H. (2020). Economic policy uncertainty and non-performing loans: The moderating role of bank concentration. Finance Research Letters, 101458.

Karnizova, L., \& Li, J. C. (2014). Economic policy uncertainty, financial markets and probability of US recessions. Economics Letters, 125(2), 261-265.

Kaviani, M. S., Kryzanowski, L., Maleki, H., \& Savor, P. (2020). Policy uncertainty and corporate credit spreads. Journal of Financial Economics, 138(3), 838-865.

Keeley, M. C. (1990). Deposit insurance, risk, and market power in banking. The American Economic Review, 80(5), 1183-1200.

Keeley, M. C. \& Furlong, F. T. (1990). A reexamination of mean-variance analysis of bank capital regulations. Journal of Banking \& Finance, 14(1), 69-84.

Köhler, M. (2014). Does non-interest income make banks more risky? Retail-versus investment-oriented banks. Review of Financial Economics, 23(4), 182-193.

Laeven, L., \& Levine, R. (2009). Bank governance, regulation and risk taking. Journal of financial economics, 93(2), 259-275.

Lepetit, L., Nys, E., Rous, P., \& Tarazi, A. (2008). Bank income structure and risk: An empirical analysis of European banks. Journal of banking \& finance, 32(8), 1452-1467. 
Louzis, D., Vouldis, A. T., \& Metaxas, V. (2012). Macroeconomic and bank-specific determinants of non-performing loans in Greece: A comparative study of mortgage, business and consumer loan portfolios. Journal of Banking and Finance, 36,1012-1027.

Maddaloni, A., \& Peydró, J. L. (2011). Bank risk-taking, securitization, supervision, and low interest rates: Evidence from the Euro-area and the US lending standards. the review of financial studies, 24(6), 2121-2165.

Matousek, R., Panopoulou, E., \& Papachristopoulou, A. (2020). Policy uncertainty and the capital shortfall of global financial firms. Journal of Corporate Finance, 62, 101558.

McCarty, N. M., Poole, K. T., \& Rosenthal, H. (1997). Income redistribution and the realignment of American politics. AEI press.

McCarty, N. (2012). The policy consequences of partisan polarization in the United States. Unpublished paper, 563-588.

McDonald, R., \& Siegel, D. (1986). The value of waiting to invest. The quarterly journal of economics, 101(4), 707-727.

Mehran, H., \& Thakor, A. (2011). Bank capital and value in the cross-section. The Review of Financial Studies, 24(4), 1019-1067.

Nguyen, N. H., \& Phan, H. V. (2017). Policy uncertainty and mergers and acquisitions. Journal of Financial and Quantitative Analysis, 52(2), 613-644.

Nguyen, C. P., Le, T. H., \& Su, T. D. (2020). Economic policy uncertainty and credit growth: Evidence from a global sample. Research in International Business and Finance, 51, 101118.

Papell, D. H., \& Prodan, R. (2012). The statistical behavior of GDP after financial crises and severe recessions. The BE Journal of Macroeconomics, 12(3).

Phan, D. H. B., Iyke, B. N., Sharma, S. S., \& Affandi, Y. (2021). Economic policy uncertainty and financial stability-Is there a relation? Economic Modelling, 94, 1018-1029.

Pindyck, R. S. (1988). Irreversible investment, capacity choice, and the value of the firm. The American Economic Review, 78, 969-985.

Poghosyan, T., \&`Cihak, M. (2011). Determinants of bank distress in Europe: Evidence from a new data set. Journal of Financial Services Research, 40, 163-184.

Poole, K. T., \& Rosenthal, H. (2000). Congress: A political-economic history of roll call voting. Oxford University Press on Demand.

Rajan, R. G. (2006). Has finance made the world riskier?. European financial management, 12(4), 499-533.

Salas, V., \& Saurina, J. (2002). Credit risk in two institutional regimes: Spanish commercial and savings banks. Journal of FinancialServices Research, 22, 203-224. 
Shim, J. (2013). Bank capital buffer and portfolio risk: The influence of business cycle and revenue diversification. Journal of banking \& finance, 37(3), 761-772.

Stock, J. H., \& Yogo, M. (2005). Testing for weak instruments in linear IV regression. Identification and inference for econometric models: Essays in honor of Thomas Rothenberg, 80(4.2), 1 .

Tang, D. Y., \& Yan, H. (2010). Market conditions, default risk and credit spreads. Journal of Banking \& Finance, 34(4), 743-753.

Taylor, J. B. (2014). Across the Great Divide: New Perspectives on the Financial Crisis. Hoover Institution Press.

Uhde, A., \& Heimeshoff, U. (2009). Consolidation in banking and financial stability in Europe: Empirical evidence. Journal of Banking and Finance, 33, 1299-1311.

Wu, J., Yao, Y., Chen, M., \& Jeon, B. N. (2020). Economic uncertainty and bank risk: Evidence from emerging economies. Journal of International Financial Markets, Institutions and Money, 68, 101242.

Valencia, F. (2017). Aggregate uncertainty and the supply of credit. Journal of Banking \& Finance, 81, 150-165. 
Table 1: Variables

\begin{tabular}{|c|c|c|}
\hline Variable & Descriptions & Source \\
\hline \multicolumn{2}{|l|}{ Dependent variables } & \\
\hline ZSCORE & $\begin{array}{l}\text { The natural logarithm of the Z-score: } \mathrm{Ln}[(\mathrm{ROA}+\mathrm{EQTA}) / \mathrm{SD} \text { ROA] where ROA is the return on } \\
\text { assets, SDROA is the standard deviation of ROA calculated using three quarter rolling windows, and } \\
\text { EQTA is the equity to total assets ratio. }\end{array}$ & \multirow{8}{*}{ FitchConnect } \\
\hline ZSCORE1 & Ln [EQTA / SD ROA]; risk-adjusted capitalization & \\
\hline ZSCORE2 & Ln [ROA/SD ROA]; risk-adjusted return & \\
\hline$N P L$ & Non-performing loans to gross loans & \\
\hline$L L P$ & Loan loss provisions to gross loans & \\
\hline ZSCORE5 & $\begin{array}{l}\text { The natural logarithm of the Z-score with the same formula as above, but SD ROA is calculated using } \\
\text { five quarter rolling windows. }\end{array}$ & \\
\hline$R O A$ & Return on assets & \\
\hline$S D R O A$ & The standard deviation of ROA calculated using three quarter rolling windows & \\
\hline \multicolumn{3}{|c|}{ Uncertainty variables } \\
\hline$E P U$ & $\begin{array}{l}\text { EPU Composite index is the natural logarithm of the overall economic policy uncertainty measure. It } \\
\text { is a weighted average of the four components: } 1 / 2 \text { weight on the broad news-based policy uncertainty } \\
\text { index and weight of } 1 / 6 \text { on each of the other three components (the tax expirations index, the CPI } \\
\text { forecast disagreement measure, and the federal, state, local purchases disagreement measure). The } \\
\text { index is available monthly, and EPU is calculated quarterly by taking the natural logarithm of quarter- } \\
\text { end values. }\end{array}$ & \multirow[t]{3}{*}{ Baker et al. (2016) } \\
\hline$E P U V 2$ & $\begin{array}{l}\text { EPU V2 uses an alternative calculation method and is constructed quarterly by taking the natural } \\
\text { logarithm of the average of monthly values. }\end{array}$ & \\
\hline EPU NEWS & The natural logarithm of the news-based component of the EPU index. & \\
\hline \multicolumn{2}{|c|}{ Bank-Level Control Variables } & \\
\hline SIZE & The natural logarithm of total assets & \multirow{5}{*}{ FitchConnect } \\
\hline LIQTA & The ratio of liquid assets to total assets & \\
\hline$C I R$ & Operating cost to operating income ratio & \\
\hline GTA & Growth of total assets & \\
\hline NII & The ratio of total non-interest income to gross revenues & \\
\hline \multicolumn{3}{|l|}{ Macro Controls } \\
\hline$R G D P G R W$ & The quarterly real GDP growth & The Federal Reserve Bank of St. Louis \\
\hline FED FUNDS RATE & The quarterly percentage change in fed funds rate & The Federal Reserve Bank of St. Louis \\
\hline CONS SENT & $\begin{array}{l}\text { The quarterly percent change in the University of Michigan's Index of Consumer Sentiment. Higher } \\
\text { values indicate that consumers are more optimistic about their finances and the state of the economy. }\end{array}$ & The Federal Reserve Bank of St. Louis \\
\hline \multicolumn{3}{|c|}{ ( } \\
\hline CASH FLOWS & $\begin{array}{l}\text { A quarterly state-level variable that is calculated as the ratio cross-sectional average of operating cash } \\
\text { flows to the lagged total assets for each firm located in the corresponding state. }\end{array}$ & Compustat \\
\hline
\end{tabular}




\begin{tabular}{|c|c|c|}
\hline TOBINS $Q$ & $\begin{array}{l}\text { A quarterly state-level variable which is calculated as the ratio cross-sectional average of Tobins } Q \\
\text { for each firm located in the corresponding state. Tobin's } Q \text { is defined as the ratio of the market value } \\
\text { of assets to the book value of assets. }\end{array}$ & Compustat \\
\hline \multicolumn{3}{|c|}{ Heterogeneity analyses } \\
\hline TIERI & $\begin{array}{l}\text { The tier } 1 \text { regulatory capital ratio is the ratio of core tier } 1 \text { capital (its equity capital and disclosed } \\
\text { reserves) to its total risk-weighted assets. }\end{array}$ & FitchConnect \\
\hline$R E G C A P$ & $\begin{array}{l}\text { The total regulatory capital ratio is the ratio of the sum of tier } 1 \text { and tier } 2 \text { capital (hybrid capital, } \\
\text { subordinated debt, reserves for loan losses, and valuation reserves) to its total risk-weighted assets. }\end{array}$ & FitchConnect \\
\hline DEPLOANS & The ratio of deposits to net loans. & FitchConnect \\
\hline \multicolumn{3}{|c|}{ Instrumental variable } \\
\hline POLARIZ & $\begin{array}{l}\text { Senate polarization index as an instrumental variable for economic policy uncertainty. The index } \\
\text { quantifies the level of political polarization in the US Senate (McCarty et al., 1997). }\end{array}$ & https://www.voteview.com/data \\
\hline
\end{tabular}

Note: This table provides brief definitions and sources for the variables used in our analyses for the period 2011 Q1 - 2020 Q3. 
Table 2: Descriptive Statistics

\begin{tabular}{|c|c|c|c|c|c|c|c|c|}
\hline Variable & Obs. & Mean & Min & Max & p25 & p50 & p75 & Std. dev. \\
\hline \multicolumn{9}{|l|}{ Dependent variables } \\
\hline ZSCORE & 193,966 & 2.50 & -3.91 & 5.18 & 1.89 & 2.57 & 3.23 & 1.24 \\
\hline ZSCORE1 & 193,975 & 1.86 & -2.07 & 41.85 & 1.13 & 1.87 & 2.60 & 1.17 \\
\hline ZSCORE2 & 193,840 & 3.14 & -1.89 & 36.52 & 2.90 & 3.05 & 3.28 & 0.43 \\
\hline$N P L(\%)$ & 194,083 & 1.98 & 0.00 & 14.20 & 0.34 & 1.10 & 2.53 & 2.56 \\
\hline LLP $(\%)$ & 201,320 & 0.29 & -0.80 & 3.77 & 0.00 & 0.11 & 0.32 & 0.59 \\
\hline ZSCORE5 & 189,926 & -2.28 & -37.19 & 7.24 & -2.92 & -2.33 & -1.68 & 1.56 \\
\hline$R O A$ & 200546 & 8.50 & -28 & 31.11 & 5.19 & 8.59 & 12.3 & 7.89 \\
\hline SD ROA & 196258 & 3.00 & 0 & 41.80 & 0.84 & 1.66 & 3.40 & 3.91 \\
\hline \multicolumn{9}{|l|}{ Uncertainty variables } \\
\hline$E P U$ & 220,506 & 4.88 & 4.38 & 5.65 & 4.65 & 4.90 & 5.11 & 0.31 \\
\hline EPU NEWS & 220,506 & 5.02 & 4.45 & 6.05 & 4.75 & 5.04 & 5.25 & 0.37 \\
\hline$E P U V 2$ & 220,506 & 4.87 & 4.35 & 5.65 & 4.68 & 4.81 & 5.04 & 0.28 \\
\hline \multicolumn{9}{|l|}{ Bank-Level Control Variables } \\
\hline SIZE & 200,646 & 5.49 & 0.35 & 14.99 & 4.54 & 5.27 & 6.13 & 1.52 \\
\hline Total assets (millions USD) & 200,647 & $5,317.14$ & 0.00 & $324,6076.00$ & 93.46 & 194.08 & 458.68 & $78,019.40$ \\
\hline$N I I(\%)$ & 202,351 & 16.90 & -7.27 & 78.08 & 8.96 & 14.3 & 21.25 & 13.02 \\
\hline LIQTA $(\%)$ & 202,386 & 10.92 & 1.15 & 50.03 & 4.54 & 8.26 & 14.20 & 9.18 \\
\hline $\operatorname{CIR}(\%)$ & 202,375 & 69.82 & 30.53 & 143.47 & 58.99 & 68.07 & 78.47 & 17.68 \\
\hline GTA & 202,291 & 3.55 & -13.45 & 45.14 & -0.80 & 2.10 & 5.90 & 8.37 \\
\hline \multicolumn{9}{|l|}{ Macro Controls } \\
\hline$R G D P G R W(\%)$ & 220,506 & 0.45 & -8.99 & 7.48 & 0.31 & 0.57 & 0.78 & 1.94 \\
\hline FED FUNDS RATE (\%) & 220,506 & 7.03 & -95.24 & 125.00 & -10.71 & 8.26 & 20.05 & 33.13 \\
\hline CONS SENT & 220,506 & 0.37 & -23.35 & 16.51 & -1.64 & 0.29 & 3.62 & 6.38 \\
\hline \multicolumn{9}{|l|}{ Demand Controls } \\
\hline CASH FLOWS (\%) & 219,063 & 0.02 & -0.07 & 0.12 & 0.00 & 0.02 & 0.04 & 0.03 \\
\hline TOBINS $Q(\%)$ & 219,063 & 2.04 & 1.30 & 2.83 & 1.84 & 2.01 & 2.20 & 0.31 \\
\hline \multicolumn{9}{|l|}{ Heterogeneity analyses } \\
\hline TIERI $(\%)$ & 197,192 & 17.03 & 8.00 & 56.33 & 12.43 & 14.84 & 18.80 & 7.65 \\
\hline$R E G C A P(\%)$ & 197,201 & 18.16 & 9.30 & 57.21 & 13.59 & 16.00 & 19.92 & 7.62 \\
\hline DEPLOANS (\%) & 202,198 & 1.52 & 0.86 & 5.19 & 1.13 & 1.32 & 1.64 & 0.68 \\
\hline
\end{tabular}

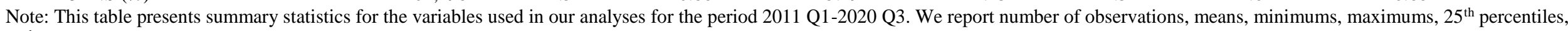
$75^{\text {th }}$ percentiles and standard deviations on all the regression variables that are used to investigate the impact of EPU on bank stability. 
Table 3: Effect of EPU on Bank Stability-Baseline Estimations

\begin{tabular}{|c|c|c|c|c|c|c|}
\hline & (1) Macro Controls & (2) Macro Controls; CONS SENT & (3) Demand Controls & (4) State FE & (5) ZSCORE1 & (6) ZSCORE2 \\
\hline \multirow[t]{2}{*}{$E P U$} & $-2.466^{* * *}$ & $-1.295^{* * *}$ & $-1.216^{* * *}$ & $-0.332^{* * *}$ & $-2.964^{* * *}$ & $-1.128^{* * *}$ \\
\hline & $(0.29)$ & $(0.24)$ & $(0.25)$ & $(0.01)$ & $(0.22)$ & $(0.09)$ \\
\hline \multirow[t]{2}{*}{ SIZE } & -0.010 & -0.010 & -0.009 & $0.071^{* * *}$ & -0.011 & 0.001 \\
\hline & $(0.01)$ & $(0.01)$ & $(0.01)$ & $(0.01)$ & $(0.01)$ & $(0.01)$ \\
\hline \multirow[t]{2}{*}{$N I I$} & $-0.014^{* * *}$ & $-0.014^{* * *}$ & $-0.014^{* * *}$ & $-0.008^{* * *}$ & $-0.014^{* * *}$ & $-0.004^{* * *}$ \\
\hline & $(0.00)$ & $(0.00)$ & $(0.00)$ & $(0.00)$ & $(0.00)$ & $(0.00)$ \\
\hline \multirow[t]{2}{*}{ LIQTA } & $-0.002^{*}$ & $-0.002^{*}$ & $-0.002^{*}$ & 0.000 & $0.002^{* *}$ & $-0.001^{* * *}$ \\
\hline & $(0.00)$ & $(0.00)$ & $(0.00)$ & $(0.00)$ & $(0.00)$ & $(0.00)$ \\
\hline \multirow[t]{2}{*}{$C I R$} & $-0.018^{* * *}$ & $-0.018^{* * *}$ & $-0.018^{* * *}$ & $-0.027^{* * *}$ & $-0.009^{* * *}$ & $-0.005^{* * *}$ \\
\hline & $(0.00)$ & $(0.00)$ & $(0.00)$ & $(0.00)$ & $(0.00)$ & $(0.00)$ \\
\hline \multirow[t]{2}{*}{$G T A$} & $0.003^{* * *}$ & $0.003^{* * *}$ & $0.003^{* * *}$ & $0.002^{* *}$ & $-0.002^{* * *}$ & 0.000 \\
\hline & $(0.00)$ & $(0.00)$ & $(0.00)$ & $(0.00)$ & $(0.00)$ & $(0.00)$ \\
\hline \multirow[t]{2}{*}{$R G D P G R W$} & $-0.843^{* * *}$ & $-0.446^{* * *}$ & $-0.423^{* * *}$ & $-0.107^{* * *}$ & $-1.000^{* * *}$ & $-0.412^{* * *}$ \\
\hline & $(0.11)$ & $(0.09)$ & $(0.09)$ & $(0.01)$ & $(0.08)$ & $(0.03)$ \\
\hline \multirow[t]{2}{*}{ FED FUNDS RATE } & $0.003^{\text {*** }}$ & $0.017^{\text {**** }}$ & $0.017^{* * * *}$ & $0.001^{* * * *}$ & $0.014^{* * * *}$ & $0.006^{* * * *}$ \\
\hline & $(0.00)$ & $(0.00)$ & $(0.00)$ & $(0.00)$ & $(0.00)$ & $(0.00)$ \\
\hline \multirow[t]{2}{*}{ COVID19 } & $-6.798^{* * * *}$ & $-2.049^{* * * *}$ & $-1.844^{* * *}$ & $-0.834^{* * * *}$ & $-6.753^{* * * *}$ & $-2.819^{* * * *}$ \\
\hline & $(0.94)$ & $(0.76)$ & $(0.78)$ & $(0.05)$ & $(0.69)$ & $(0.27)$ \\
\hline \multirow[t]{2}{*}{ CONS SENT } & & $0.020^{* * *}$ & $0.020^{* * * *}$ & $0.005^{* * *}$ & $0.021^{* * *}$ & $0.008^{* * *}$ \\
\hline & & $(0.00)$ & $(0.00)$ & $(0.00)$ & $(0.00)$ & $(0.00)$ \\
\hline \multirow[t]{2}{*}{ CASH FLOWS } & & & $0.253^{* * *}$ & -0.161 & $0.161^{*}$ & 0.015 \\
\hline & & & $(0.14)$ & $(0.11)$ & $(0.13)$ & $(0.05)$ \\
\hline \multirow[t]{2}{*}{ TOBINS Q } & & & $0.027 *$ & $0.091^{* * * *}$ & -0.015 & 0.001 \\
\hline & & & $(0.02)$ & $(0.02)$ & $(0.02)$ & $(0.01)$ \\
\hline \multirow[t]{2}{*}{ Constant } & $16.730^{* * *}$ & $10.949^{* * *}$ & $10.493^{* * *}$ & $5.687^{* * * *}$ & $18.296^{* * *}$ & $9.446^{* * *}$ \\
\hline & $(1.45)$ & (1.24) & (1.29) & $(0.12)$ & $(1.15)$ & $(0.45)$ \\
\hline R2 & 0.311 & 0.311 & 0.309 & 0.200 & 0.099 & 0.345 \\
\hline Number of observations & 177142 & 177142 & 176477 & 176477 & 176485 & 176369 \\
\hline Number of banks & 5620 & 5620 & 5584 & 5620 & 5584 & 5583 \\
\hline Bank FE & YES & YES & YES & NO & YES & YES \\
\hline Quarter FE & YES & YES & YES & YES & YES & YES \\
\hline State FE & NO & NO & NO & YES & NO & NO \\
\hline
\end{tabular}

Note: This table displays the baseline regression results of the impact of $E P U$ on bank stability. Columns 1-4 use ZSCORE as dependent variables. Columns 5\&6 decompose the ZSCORE, and use ZSCORE1 and ZSCORE2 as dependent variables, respectively. We implement panel data estimation techniques for a sample of US commercial banks for the period $2011 \mathrm{Q} 1$ and 2020 Q3. All columns use bank and quarter fixed effects except for Column 4, which uses state and quarter fixed effects. The first-lag of all explanatory variables is included to mitigate any potential reverse causality. Standard errors are clustered at the bank level and given in parentheses. ${ }^{*} p<0.1,{ }^{* *} p<0.05,{ }^{* * *} p<0.01$ 
Table 4: Effect of EPU on Bank stability- IV Estimations

\begin{tabular}{|c|c|c|c|c|}
\hline & $\begin{array}{c}\text { (1) First stage } \\
E P U\end{array}$ & $\begin{array}{l}\text { (2) Second Stage } \\
\text { ZSCORE }\end{array}$ & $\begin{array}{l}\text { (3) Second Stage } \\
\text { ZSCORE1 }\end{array}$ & $\begin{array}{l}\text { (4) Second Stage } \\
\text { ZSCORE2 }\end{array}$ \\
\hline$E P U$ & & $-0.843^{* * *}$ & $-0.707^{* * *}$ & $-0.183^{* * *}$ \\
\hline & & $(0.04)$ & $(0.03)$ & $(0.01)$ \\
\hline POLARIZ & $\begin{array}{l}2.971 * * * \\
(0.02)\end{array}$ & & & \\
\hline SIZE & $\begin{array}{l}-2.333 \\
(1.39)\end{array}$ & $\begin{array}{l}-0.011 \\
(0.02)\end{array}$ & $\begin{array}{l}-0.015 \\
(0.02)\end{array}$ & $\begin{array}{r}-0.001 \\
(0.01)\end{array}$ \\
\hline$N I I$ & $\begin{array}{c}-0.084 * \\
(0.04)\end{array}$ & $\begin{array}{c}-0.014^{* * * *} \\
(0.00)\end{array}$ & $\begin{array}{c}-0.014^{* * *} \\
(0.00)\end{array}$ & $\begin{array}{c}-0.004^{* * *} \\
(0.00)\end{array}$ \\
\hline LIQTA & $\begin{array}{c}0.056^{* *} \\
(0.02)\end{array}$ & $\begin{array}{l}-0.002 \\
(0.00)\end{array}$ & $\begin{array}{c}0.002^{* * *} \\
(0.00)\end{array}$ & $\begin{array}{c}-0.002^{* * * *} \\
(0.00)\end{array}$ \\
\hline$C I R$ & $\begin{array}{l}-0.008 \\
(0.02)\end{array}$ & $\begin{array}{c}-0.018^{* * *} \\
(0.00)\end{array}$ & $\begin{array}{c}-0.009^{* * *} \\
(0.00)\end{array}$ & $\begin{array}{c}-0.005^{* * *} \\
(0.00)\end{array}$ \\
\hline GTA & $\begin{array}{l}-0.050 \\
(0.03)\end{array}$ & $\begin{array}{c}0.003^{* * * *} \\
(0.00)\end{array}$ & $\begin{array}{c}-0.001^{* *} \\
(0.00)\end{array}$ & $\begin{array}{l}0.000 \\
(0.00)\end{array}$ \\
\hline$R G D P G R W$ & $\begin{array}{c}-0.073^{*} \\
(0.07)\end{array}$ & $\begin{array}{c}-0.245^{* * *} \\
(0.01)\end{array}$ & $\begin{array}{c}-0.270^{* * *} \\
(0.01)\end{array}$ & $\begin{array}{c}-0.070^{* * *} \\
(0.00)\end{array}$ \\
\hline FED FUNDS RATE & $\begin{array}{l}-0.002 \\
(0.00)\end{array}$ & $\begin{array}{l}0.001^{* * * * *} \\
(0.00)\end{array}$ & $\begin{array}{c}0.001^{* * * *} \\
(0.00)\end{array}$ & $\begin{array}{c}0.000^{* * * *} \\
(0.00)\end{array}$ \\
\hline CONS SENT & $\begin{array}{c}-0.001 * \\
(0.00)\end{array}$ & $\begin{array}{l}0.001 \\
(0.00)\end{array}$ & $\begin{array}{l}-0.001 \\
(0.00)\end{array}$ & $\begin{array}{l}-0.000 \\
(0.00)\end{array}$ \\
\hline CASH FLOWS & $\begin{array}{l}3.529 \\
(4.57)\end{array}$ & $\begin{array}{c}0.693^{* * * *} \\
(0.14)\end{array}$ & $\begin{array}{c}0.616^{* * * *} \\
(0.13)\end{array}$ & $\begin{array}{c}0.208^{* * * *} \\
(0.05)\end{array}$ \\
\hline TOBINS $Q$ & $\begin{array}{l}-2.211 * * * \\
(0.46)\end{array}$ & $\begin{array}{l}0.041^{* *} \\
(0.02)\end{array}$ & $\begin{array}{l}0.023 \\
(0.02)\end{array}$ & $\begin{array}{l}0.010 \\
(0.01)\end{array}$ \\
\hline Constant & $\begin{array}{c}26.060 * * * \\
(8.26)\end{array}$ & $\begin{array}{c}8.101^{* * * *} \\
(0.22)\end{array}$ & $\begin{array}{c}6.240^{* * * *} \\
(0.20)\end{array}$ & $\begin{array}{c}4.437^{* * * *} \\
(0.07)\end{array}$ \\
\hline Adjusted R2 & 0.6562 & 0.303 & 0.088 & 0.323 \\
\hline Number of observations & 36 & 168430 & 168438 & 168326 \\
\hline Number of banks & & 5575 & 5575 & 5575 \\
\hline Bank FE & No & Yes & Yes & Yes \\
\hline Quarter FE & Yes & Yes & Yes & Yes \\
\hline
\end{tabular}

Note: This table presents the findings from the instrumental variable analysis. We implement a two-stage least-squares regressions approach with the U.S. Senate polarization measure (POLARIZ) as an instrumental variable for $E P U$. The first column presents the first stage regression results, and Columns 2-4 show the second-stage estimation results for the dependent variables ZSCORE, ZSCORE1 and ZSCORE2, respectively. The sample period for the Senate polarization is 2011 Q1 to 2019 Q4. Standard errors in parentheses. ${ }^{*} p<0.1,{ }^{* *} p<0.05,{ }^{* * *} p<0.01$ 
Table 5: Effect of EPU on Bank stability- Robustness Checks for the Baseline Estimations

\begin{tabular}{|c|c|c|c|c|c|c|c|}
\hline & (1) $E P U N E W S$ & (2) $E P U V 2$ & (3) NPL & (4) $L L P$ & (5) ZSCORE5 & (6) $S D R O A$ & (7) $\mathrm{ROA}$ \\
\hline \multirow[t]{2}{*}{$E P U$} & $-0.133^{* * *}$ & $-0.476^{* * *}$ & $1.055^{* * *}$ & $0.277^{* * *}$ & $-0.242^{* * *}$ & $3.608^{* * * *}$ & -0.077 \\
\hline & $(0.01)$ & $(0.02)$ & $(0.03)$ & $(0.01)$ & $(0.01)$ & $(0.77)$ & $(0.08)$ \\
\hline \multirow[t]{2}{*}{ SIZE } & -0.001 & -0.011 & -0.026 & -0.006 & -0.010 & 0.038 & 0.115 \\
\hline & $(0.02)$ & $(0.01)$ & $(0.04)$ & $(0.01)$ & $(0.01)$ & $(0.05)$ & $(0.09)$ \\
\hline \multirow[t]{2}{*}{ NII } & $-0.015^{* * * *}$ & $-0.014^{* * * *}$ & $0.014^{* * *}$ & -0.000 & $-0.011^{* * *}$ & $0.064^{* * * *}$ & $-0.043^{* * *}$ \\
\hline & $(0.00)$ & $(0.00)$ & $(0.00)$ & $(0.00)$ & $(0.00)$ & $(0.00)$ & $(0.01)$ \\
\hline \multirow[t]{2}{*}{ LIQTA } & $-0.005^{* * *}$ & $-0.003^{* * *}$ & $0.020^{* * *}$ & -0.001 & $-0.003^{* * *}$ & -0.000 & $-0.085^{* * *}$ \\
\hline & $(0.00)$ & $(0.00)$ & $(0.00)$ & $(0.00)$ & $(0.00)$ & $(0.00)$ & $(0.01)$ \\
\hline$C I R$ & $(0.00)$ & $(0.00)$ & $(0.00)$ & $(0.00)$ & $(0.00)$ & $(0.00)$ & $(0.00)$ \\
\hline \multirow[t]{2}{*}{ GTA } & $0.002^{* * *}$ & $0.002^{* * *}$ & $-0.036^{* * *}$ & $-0.002^{* * *}$ & $0.001^{* * *}$ & $-0.009^{* * *}$ & $0.065^{* * *}$ \\
\hline & $(0.00)$ & $(0.00)$ & $(0.00)$ & $(0.00)$ & $(0.00)$ & $(0.00)$ & $(0.00)$ \\
\hline \multirow[t]{2}{*}{$R G D P G R W$} & $-0.060^{* * * *}$ & $-0.097^{* * *}$ & $0.311^{* * *}$ & -0.001 & $-0.090^{* * *}$ & $1.175^{\text {*** }}$ & -0.011 \\
\hline & $(0.00)$ & $(0.00)$ & $(0.01)$ & $(0.00)$ & $(0.00)$ & $(0.29)$ & $(0.03)$ \\
\hline \multirow[t]{2}{*}{ FED FUNDS RATE } & $0.002^{* * *}$ & $0.002^{* * *}$ & $-0.004^{* * *}$ & $-0.001^{* * *}$ & $0.001^{* * *}$ & $-0.029^{* * * *}$ & $0.005^{* * *}$ \\
\hline & $(0.00)$ & $(0.00)$ & $(0.00)$ & $(0.00)$ & $(0.00)$ & $(0.00)$ & $(0.00)$ \\
\hline COVID19 & $-0.430^{* * *}$ & $-0.544^{* * *}$ & $1.941^{* * *}$ & $-0.295^{\text {*** }}$ & $-0.714^{* * *}$ & $6.708^{* * * *}$ & $1.799^{* * *}$ \\
\hline \multirow[t]{2}{*}{ CONS SENT } & $0.004^{* * * *}$ & $0.002^{* * * *}$ & $0.010^{* * *}$ & $-0.003^{* * * *}$ & $0.002^{* * *}$ & $-0.041^{* * *}$ & $0.067^{* * *}$ \\
\hline & $(0.00)$ & $(0.00)$ & $(0.00)$ & $(0.00)$ & $(0.00)$ & $(0.00)$ & $(0.00)$ \\
\hline \multirow[t]{2}{*}{ CASH FLOWS } & $-0.461^{* * *}$ & $-0.241^{* *}$ & $1.570^{* * *}$ & $-0.295^{* * *}$ & -0.063 & -0.801 & $-5.411^{* * *}$ \\
\hline & $(0.11)$ & $(0.11)$ & $(0.25)$ & $(0.06)$ & (0.09) & $(0.52)$ & $(0.66)$ \\
\hline \multirow[t]{2}{*}{ TOBINS $Q$} & $0.171^{* * *}$ & $0.068^{* * *}$ & $-0.219^{* * *}$ & $-0.042^{\text {*** }}$ & $0.066^{* * *}$ & -0.060 & $0.588^{* * *}$ \\
\hline & $(0.02)$ & $(0.02)$ & $(0.04)$ & $(0.01)$ & $(0.02)$ & $(0.08)$ & $(0.11)$ \\
\hline \multirow{2}{*}{ Constant } & $4.391^{* * *}$ & $6.281^{* * *}$ & $-5.009^{* * *}$ & $-0.873^{* * *}$ & $4.410^{* * *}$ & $-19.704^{* * *}$ & $16.562^{* * *}$ \\
\hline & $(0.12)$ & $(0.14)$ & $(0.34)$ & $(0.07)$ & $(0.12)$ & $(4.02)$ & $(0.78)$ \\
\hline $\mathrm{R} 2$ & 0.298 & 0.303 & 0.108 & 0.04 & 0.219 & 0.128 & 0.394 \\
\hline Number of observations & 176477 & 176477 & 171207 & 177977 & 175024 & 178390 & 177283 \\
\hline Number of banks & 5584 & 5584 & 5559 & 5562 & 5585 & 5587 & 5587 \\
\hline Bank FE & YES & YES & YES & YES & YES & YES & YES \\
\hline Quarter FE & YES & YES & YES & YES & YES & YES & YES \\
\hline
\end{tabular}

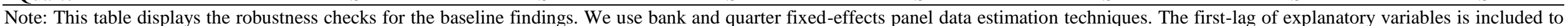

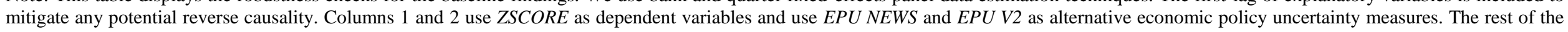

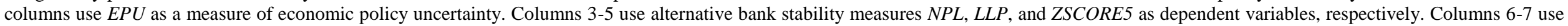
$S D$ ROA and ROA as dependent variables, respectively. Standard errors are clustered at the bank level and given in parentheses. ${ }^{*} p<0.1,{ }^{* *} p<0.05,{ }^{* * *} p<0.01$ 
Table 6: Effect of EPU on bank stability: The heterogeneity in bank size

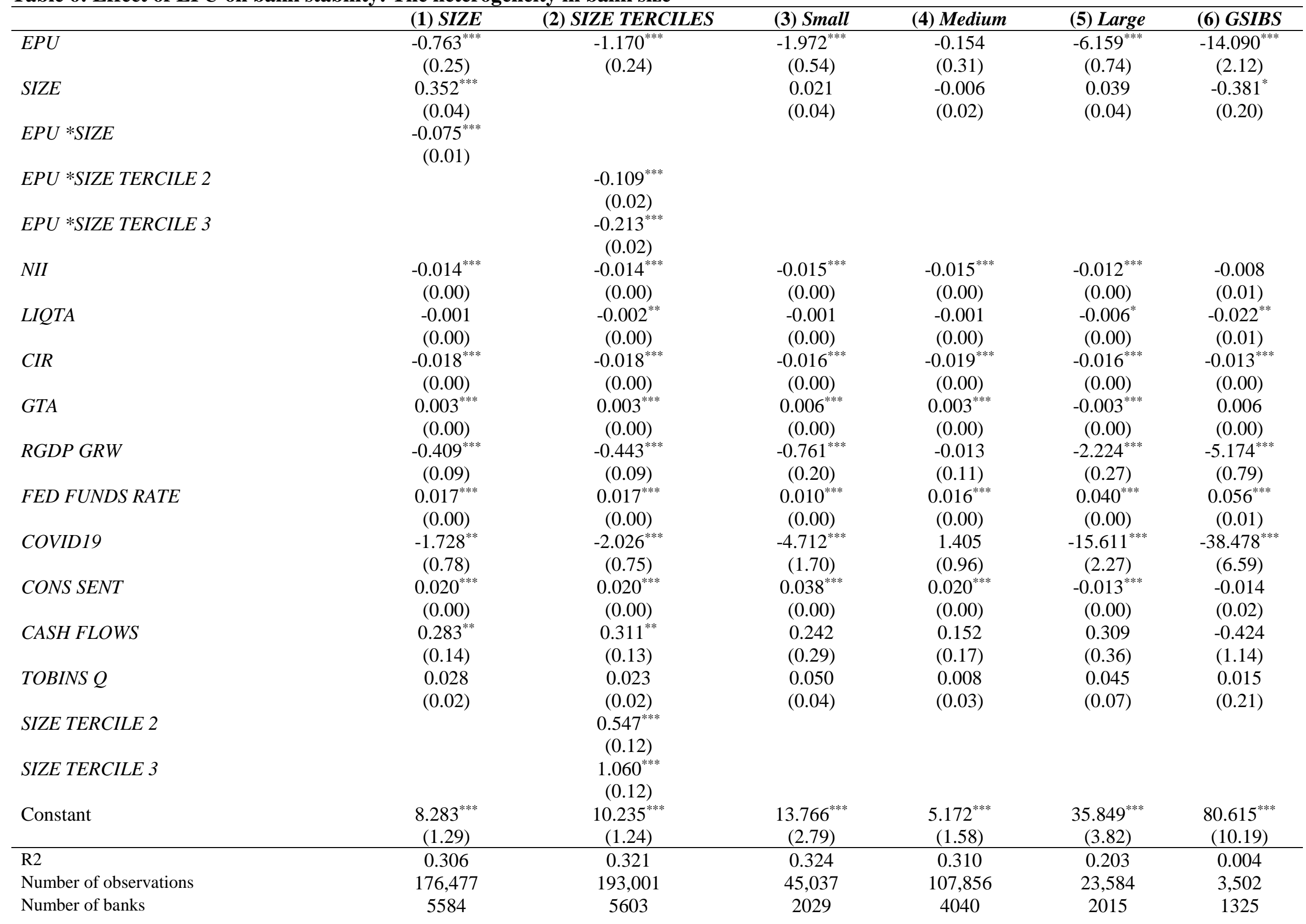




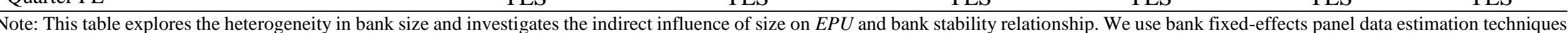

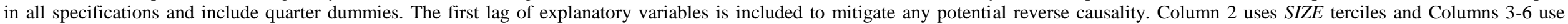

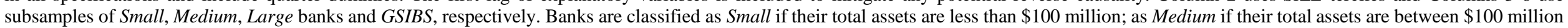

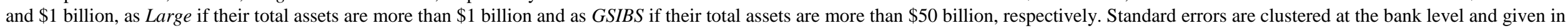
parentheses. ${ }^{*} p<0.1,{ }^{* *} p<0.05,{ }^{* * * *} p<0.01$ 
Table 7: Effect of EPU on bank stability-The impact of capital

\begin{tabular}{|c|c|c|c|c|c|c|}
\hline & (1) EQTA & $\begin{array}{c}\text { (2) EQTA } \\
\text { TERCILES }\end{array}$ & (3) EQTA LOW & (4) EQTA HIGH & (5) TIERI & (6) $R E G C A P$ \\
\hline$E P U$ & $\begin{array}{c}-2.713^{* * *} \\
(0.24)\end{array}$ & $\begin{array}{c}-2.102^{* * * *} \\
(0.25)\end{array}$ & $\begin{array}{c}-0.400^{* * * *} \\
(0.01)\end{array}$ & $\begin{array}{c}-0.232^{* * * *} \\
(0.01)\end{array}$ & $\begin{array}{c}-1.925^{* * *} \\
(0.25)\end{array}$ & $\begin{array}{c}-1.885^{* * *} \\
(0.25)\end{array}$ \\
\hline$E Q T A$ & $\begin{array}{l}-0.024 \\
(0.02)\end{array}$ & & & & & \\
\hline$E P U * E Q T A$ & $\begin{array}{c}0.023^{* * * *} \\
(0.00)\end{array}$ & & & & & \\
\hline EPU *EQTA TERCILE 2 & & $\begin{array}{c}0.080^{* * * *} \\
(0.03)\end{array}$ & & & & \\
\hline EPU *EQTA TERCILE 3 & & $\begin{array}{c}0.148^{* * *} \\
(0.03)\end{array}$ & & & & \\
\hline TIERI & & & & & $\begin{array}{c}-0.032^{* * *} \\
(0.01)\end{array}$ & \\
\hline$E P U * T I E R I$ & & & & & $\begin{array}{c}0.013^{* * * *} \\
(0.00)\end{array}$ & \\
\hline REG CAP & & & & & & $\begin{array}{c}-0.031^{* * *} \\
(0.01)\end{array}$ \\
\hline EPU *REG CAP & & & & & & $\begin{array}{c}0.013^{* * * *} \\
(0.00)\end{array}$ \\
\hline SIZE & $\begin{array}{l}-0.006 \\
(0.01)\end{array}$ & $\begin{array}{l}-0.006 \\
(0.01)\end{array}$ & $\begin{array}{c}0.093^{* * * *} \\
(0.01)\end{array}$ & $\begin{array}{c}0.079^{* * * *} \\
(0.01)\end{array}$ & $\begin{array}{l}-0.009 \\
(0.01)\end{array}$ & $\begin{array}{l}-0.008 \\
(0.01)\end{array}$ \\
\hline NII & $\begin{array}{c}-0.015^{* * *} \\
(0.00)\end{array}$ & $\begin{array}{c}-0.015^{* * * *} \\
(0.00)\end{array}$ & $\begin{array}{c}-0.014^{* * * *} \\
(0.00)\end{array}$ & $\begin{array}{c}-0.013^{* * * *} \\
(0.00)\end{array}$ & $\begin{array}{c}-0.015^{* * *} \\
(0.00)\end{array}$ & $\begin{array}{c}-0.015^{* * * *} \\
(0.00)\end{array}$ \\
\hline LIQTA & $\begin{array}{l}-0.001 \\
(0.00)\end{array}$ & $\begin{array}{l}-0.001 \\
(0.00)\end{array}$ & $\begin{array}{c}-0.006^{* * * *} \\
(0.00)\end{array}$ & $\begin{array}{c}-0.004^{* * * *} \\
(0.00)\end{array}$ & $\begin{array}{c}-0.007^{* * * *} \\
(0.00)\end{array}$ & $\begin{array}{c}-0.007^{* * * *} \\
(0.00)\end{array}$ \\
\hline$C I R$ & $\begin{array}{c}-0.018^{* * * *} \\
(0.00)\end{array}$ & $\begin{array}{c}-0.018^{* * * *} \\
(0.00)\end{array}$ & $\begin{array}{c}-0.025^{* * * *} \\
(0.00)\end{array}$ & $\begin{array}{c}-0.012^{* * * *} \\
(0.00)\end{array}$ & $\begin{array}{c}-0.018^{* * * *} \\
(0.00)\end{array}$ & $\begin{array}{c}-0.018^{* * * * *} \\
(0.00)\end{array}$ \\
\hline GTA & $\begin{array}{c}0.005^{* * * *} \\
(0.00)\end{array}$ & $\begin{array}{c}0.004^{* * * *} \\
(0.00)\end{array}$ & $\begin{array}{c}0.006^{* * * *} \\
(0.00)\end{array}$ & $\begin{array}{c}-0.003^{* * *} \\
(0.00)\end{array}$ & $\begin{array}{c}0.004^{* * * *} \\
(0.00)\end{array}$ & $\begin{array}{c}0.004^{* * *} \\
(0.00)\end{array}$ \\
\hline$R G D P G R W$ & $\begin{array}{c}-0.892^{* * * *} \\
(0.09)\end{array}$ & $\begin{array}{c}-0.729^{* * * *} \\
(0.09)\end{array}$ & $\begin{array}{c}-0.117^{* * * *} \\
(0.01)\end{array}$ & $\begin{array}{c}-0.079^{* * * *} \\
(0.01)\end{array}$ & $\begin{array}{c}-0.597^{* * * *} \\
(0.09)\end{array}$ & $\begin{array}{c}-0.578^{* * * *} \\
(0.09)\end{array}$ \\
\hline FED FUNDS RATE & $\begin{array}{c}0.015^{* * *} \\
(0.00)\end{array}$ & $\begin{array}{c}0.016^{* * *} \\
(0.00)\end{array}$ & $\begin{array}{c}0.001^{* * * *} \\
(0.00)\end{array}$ & $\begin{array}{c}0.001^{* * * *} \\
(0.00)\end{array}$ & $\begin{array}{c}0.016^{* * *} \\
(0.00)\end{array}$ & $\begin{array}{c}0.016^{* * * *} \\
(0.00)\end{array}$ \\
\hline COVID19 & $\begin{array}{c}-5.717^{* * * *} \\
(0.76)\end{array}$ & $\begin{array}{c}-4.361^{* * * *} \\
(0.77)\end{array}$ & $\begin{array}{c}-0.907^{* * * *} \\
(0.08)\end{array}$ & $\begin{array}{c}-0.622^{* * * *} \\
(0.07)\end{array}$ & $\begin{array}{c}-3.335^{* * * *} \\
(0.77)\end{array}$ & $\begin{array}{c}-3.181^{* * * *} \\
(0.77)\end{array}$ \\
\hline CONS SENT & $\begin{array}{c}0.024^{* * * *} \\
(0.00)\end{array}$ & $\begin{array}{c}0.022^{* * * *} \\
(0.00)\end{array}$ & $\begin{array}{c}0.006^{* * * *} \\
(0.00)\end{array}$ & $\begin{array}{c}0.003^{* * *} \\
(0.00)\end{array}$ & $\begin{array}{c}0.022^{* * * *} \\
(0.00)\end{array}$ & $\begin{array}{c}0.021^{* * * *} \\
(0.00)\end{array}$ \\
\hline CASH FLOWS & $\begin{array}{l}0.184 \\
(0.14)\end{array}$ & $\begin{array}{l}0.213 \\
(0.14)\end{array}$ & $\begin{array}{c}-0.186 \\
(0.14)\end{array}$ & $\begin{array}{c}-0.493^{* * * *} \\
(0.12)\end{array}$ & $\begin{array}{l}0.164 \\
(0.14)\end{array}$ & $\begin{array}{l}0.166 \\
(0.14)\end{array}$ \\
\hline
\end{tabular}




\begin{tabular}{|c|c|c|c|c|c|c|}
\hline TOBINS $Q$ & $\begin{array}{l}0.034 \\
(0.02)\end{array}$ & $\begin{array}{l}0.032 \\
(0.02)\end{array}$ & $\begin{array}{c}0.040^{* * *} \\
(0.02)\end{array}$ & $\begin{array}{l}0.006 \\
(0.02)\end{array}$ & $\begin{array}{l}0.024 \\
(0.02)\end{array}$ & $\begin{array}{l}0.025 \\
(0.02)\end{array}$ \\
\hline EQTA TERCILE 2 & & $\begin{array}{l}-0.198 \\
(0.12)\end{array}$ & & & & \\
\hline EQTA TERCILE 3 & & $\begin{array}{c}-0.387^{* * * *} \\
(0.13)\end{array}$ & & & & \\
\hline Constant & $\begin{array}{c}17.021^{* * *} \\
(1.25)\end{array}$ & $\begin{array}{c}14.776^{* * * *} \\
(1.26)\end{array}$ & $\begin{array}{c}5.722^{* * * *} \\
(0.10)\end{array}$ & $\begin{array}{c}4.469^{* * *} \\
(0.09)\end{array}$ & $\begin{array}{c}13.604^{* * * *} \\
(1.28)\end{array}$ & $\begin{array}{c}13.369^{* * * *} \\
(1.29)\end{array}$ \\
\hline R2 & 0.345 & 0.353 & 0.403 & 0.233 & 0.336 & 0.338 \\
\hline Number of observations & 176,477 & 176,477 & 87,993 & 88,219 & 173,369 & 173,376 \\
\hline Number of banks & 5584 & 558 & 433 & 4468 & 5570 & 5570 \\
\hline Bank FE & YES & YES & YES & YES & YES & YES \\
\hline Quarter FE & YES & YES & YES & YES & YES & YES \\
\hline
\end{tabular}

Note: This table explores the heterogeneity in bank capital levels and investigates the indirect influence of $E O T A$ on $E P U$ and bank stability relationship. We use bank fixed-effects panel data estimation techniques in all specifications and include quarter dummies. The first lag of explanatory variables is included to mitigate any potential reverse causality. Column 2 uses $E Q T A$ terciles and Columns 3 and 4 use subsamples of EQTA LOW (EQTA<median) and EQTA HIGH (EQTA>median), respectively. Columns 5 and 6 use alternative capital ratios, TIERI and REGCAP. Standard errors are clustered at the bank level and given in parentheses. ${ }^{*} p<0.1,{ }^{* *} p<0.05,{ }^{* * * *} p<0.01$ 
Table 8: Effect of EPU on bank default risk- The impact of liquidity

\begin{tabular}{|c|c|c|c|c|c|}
\hline & (1) LIQTA & (2) LIQTA TERCILES & (3) LIQTA LOW & (4) LIQTA HIGH & (5) DEPLOANS \\
\hline$E P U$ & $\begin{array}{c}-1.238^{* * *} \\
(0.25)\end{array}$ & $\begin{array}{c}-2.860^{* * *} \\
(0.23)\end{array}$ & $\begin{array}{c}-1.928^{* * *} \\
(0.32)\end{array}$ & $\begin{array}{c}-0.746^{* *} \\
(0.38)\end{array}$ & $\begin{array}{c}-1.307^{* * *} \\
(0.25)\end{array}$ \\
\hline LIQTA & $\begin{array}{c}-0.017^{* * * *} \\
(0.01)\end{array}$ & & $\begin{array}{r}-0.002 \\
(0.00)\end{array}$ & $\begin{array}{r}-0.001 \\
(0.00)\end{array}$ & \\
\hline$E P U * L I Q T A$ & $\begin{array}{c}0.003^{* * * *} \\
(0.00)\end{array}$ & & & & \\
\hline EPU *LIQTA TERCILE 2 & & $\begin{array}{l}-0.012 \\
(0.02)\end{array}$ & & & \\
\hline EPU *LIQTA TERCILE 3 & & $\begin{array}{l}0.054^{* * *} \\
(0.02)\end{array}$ & & & \\
\hline DEPLOANS & & & & & $\begin{array}{c}-0.438^{* * * *} \\
(0.07)\end{array}$ \\
\hline$E P U * D E P L O A N S$ & & & & & $\begin{array}{c}0.087^{* * * *} \\
(0.01)\end{array}$ \\
\hline SIZE & $\begin{array}{l}-0.009 \\
(0.01)\end{array}$ & $\begin{array}{l}-0.004 \\
(0.01)\end{array}$ & $\begin{array}{l}-0.003 \\
(0.02)\end{array}$ & $\begin{array}{l}-0.007 \\
(0.02)\end{array}$ & $\begin{array}{l}-0.010 \\
(0.01)\end{array}$ \\
\hline NII & $\begin{array}{c}-0.014^{* * * *} \\
(0.00)\end{array}$ & $\begin{array}{c}-0.017^{* * * *} \\
(0.00)\end{array}$ & $\begin{array}{c}-0.015^{* * *} \\
(0.00)\end{array}$ & $\begin{array}{c}-0.014^{* * * *} \\
(0.00)\end{array}$ & $\begin{array}{c}-0.014^{* * * *} \\
(0.00)\end{array}$ \\
\hline$C I R$ & $\begin{array}{c}-0.018^{* * * *} \\
(0.00)\end{array}$ & $\begin{array}{c}-0.014^{* * * *} \\
(0.00)\end{array}$ & $\begin{array}{c}-0.016^{* * * *} \\
(0.00)\end{array}$ & $\begin{array}{c}-0.018^{* * * *} \\
(0.00)\end{array}$ & $\begin{array}{c}-0.018^{* * * *} \\
(0.00)\end{array}$ \\
\hline GTA & $\begin{array}{c}0.003^{* * * *} \\
(0.00)\end{array}$ & $\begin{array}{l}0.000 \\
(0.00)\end{array}$ & $\begin{array}{c}-0.001^{* *} \\
(0.00)\end{array}$ & $\begin{array}{c}0.006^{* * * *} \\
(0.00)\end{array}$ & $\begin{array}{c}0.003^{* * * *} \\
(0.00)\end{array}$ \\
\hline$R G D P G R W$ & $\begin{array}{c}-0.419^{* * * *} \\
(0.09)\end{array}$ & $\begin{array}{c}-1.013^{* * * *} \\
(0.09)\end{array}$ & $\begin{array}{c}-0.656^{* * * *} \\
(0.12)\end{array}$ & $\begin{array}{c}-0.274^{*} \\
(0.14)\end{array}$ & $\begin{array}{c}-0.411^{* * * *} \\
(0.09)\end{array}$ \\
\hline FED FUNDS RATE & $\begin{array}{c}0.017^{* * * *} \\
(0.00)\end{array}$ & $\begin{array}{c}0.017^{* * * *} \\
(0.00)\end{array}$ & $\begin{array}{c}0.017^{\text {**** }} \\
(0.00)\end{array}$ & $\begin{array}{c}0.017^{* * * *} \\
(0.00)\end{array}$ & $\begin{array}{c}0.017^{* * * *} \\
(0.00)\end{array}$ \\
\hline COVID19 & $\begin{array}{c}-1.816^{* *} \\
(0.78)\end{array}$ & $\begin{array}{c}-6.599^{* * * *} \\
(0.72)\end{array}$ & $\begin{array}{c}-3.904^{* * *} \\
(0.98)\end{array}$ & $\begin{array}{l}-0.534 \\
(1.18)\end{array}$ & $\begin{array}{c}-1.737^{* *} \\
(0.79)\end{array}$ \\
\hline CONS SENT & $\begin{array}{c}0.020^{* * *} \\
(0.00)\end{array}$ & $\begin{array}{c}0.025^{* * * *} \\
(0.00)\end{array}$ & $\begin{array}{c}0.015^{* * *} \\
(0.00)\end{array}$ & $\begin{array}{c}0.024^{* * * *} \\
(0.00)\end{array}$ & $\begin{array}{c}0.020^{* * * *} \\
(0.00)\end{array}$ \\
\hline CASH FLOWS & $\begin{array}{l}0.252^{*} \\
(0.14)\end{array}$ & $\begin{array}{l}0.121 \\
(0.14)\end{array}$ & $\begin{array}{l}-0.007 \\
(0.19)\end{array}$ & $\begin{array}{l}0.367^{*} \\
(0.19)\end{array}$ & $\begin{array}{l}0.260^{*} \\
(0.14)\end{array}$ \\
\hline TOBINS $Q$ & $\begin{array}{l}0.027 \\
(0.02)\end{array}$ & $\begin{array}{l}-0.004 \\
(0.02)\end{array}$ & $\begin{array}{l}-0.015 \\
(0.03)\end{array}$ & $\begin{array}{l}0.042 \\
(0.03)\end{array}$ & $\begin{array}{l}0.027 \\
(0.02)\end{array}$ \\
\hline LIQTA TERCILE 2 & & $\begin{array}{l}0.040 \\
(0.10)\end{array}$ & & & \\
\hline LIQTA TERCILE 3 & & $\begin{array}{c}-0.310^{* * * *} \\
(0.12)\end{array}$ & & & \\
\hline Constant & $10.597^{\text {*** }}$ & $18.769^{* * *}$ & $14.187^{* * *}$ & $7.908^{* * *}$ & $10.937^{\text {*** }}$ \\
\hline
\end{tabular}




\begin{tabular}{|c|c|c|c|c|c|}
\hline & (1.29) & $(1.20)$ & (1.63) & (1.93) & $(1.30)$ \\
\hline R2 & 0.309 & 0.218 & 0.239 & 0.280 & 0.309 \\
\hline Number of observations & 176,477 & 172,598 & 89,705 & 86,772 & 176,375 \\
\hline Number of banks & 5,584 & 5,581 & 4,707 & 5,029 & 5,578 \\
\hline Bank FE & YES & YES & YES & YES & YES \\
\hline Quarter FE & YES & YES & YES & YES & YES \\
\hline
\end{tabular}

Note: This table explores the heterogeneity in bank liquidity levels and investigates the indirect influence of LIQTA on $E P U$ and default risk relationship. We use bank fixed-effects panel data estimation techniques in all specifications and include quarter dummies. The first lag of explanatory variables is included to mitigate any potential reverse causality. Column 2 uses $L I Q T A$ terciles and Columns 3 and 4 use subsamples of LIQTA LOW (LIQTA<median) and LIQTA HIGH (LIQTA>median), respectively. Columns 5 uses an alternative liquidity ratio, DEPLOANS. Standard errors are clustered at the bank level and given in parentheses. ${ }^{*} p<0.1,{ }^{* *} p<0.05,{ }^{* * *} p<0.01$ 


\section{Appendix}

Table A1: Correlations

\begin{tabular}{|c|c|c|c|c|c|c|c|c|c|c|c|}
\hline & (1) & (2) & (3) & (4) & (5) & (6) & (7) & (8) & (9) & (10) & (11) \\
\hline (1) ZSCORE & 1 & & & & & & & & & & \\
\hline (2) ZSCORE1 & $0.8597 *$ & 1 & & & & & & & & & \\
\hline (3) ZSCORE2 & $0.7012 *$ & $0.7377 *$ & 1 & & & & & & & & \\
\hline (5) $E P U$ & $-0.0690 *$ & $-0.0639 *$ & $-0.0480 *$ & $-0.0390 *$ & 1 & & & & & & \\
\hline (6) EPU NEWS & $-0.0302 *$ & $-0.0345^{*}$ & $-0.0243^{*}$ & $-0.0125^{*}$ & $0.9077 *$ & 1 & & & & & \\
\hline (7) $E P U V 2$ & $-0.0686^{*}$ & $-0.0676^{*}$ & $-0.0485^{*}$ & $-0.0384 *$ & $0.8888 *$ & $0.7664 *$ & 1 & & & & \\
\hline (8) SIZE & $0.1538 *$ & $0.1297 *$ & $0.1791 *$ & $0.1641 *$ & -0.0028 & -0.0026 & -0.0026 & 1 & & & \\
\hline (9) NII & $-0.0346^{*}$ & $-0.0831 *$ & $-0.0066^{*}$ & $-0.0331 *$ & $0.0131 *$ & 0.0015 & $0.0190^{*}$ & $0.2778^{*}$ & 1 & & \\
\hline (10) LQTA & $-0.1303^{*}$ & $-0.0844 *$ & $-0.1445^{*}$ & $-0.1342 *$ & $0.0432 *$ & $0.0188^{*}$ & $0.0550 *$ & $-0.2357^{*}$ & $0.1070 *$ & 1 & \\
\hline (11) $C I R$ & $-0.4725^{*}$ & $-0.2479 *$ & $-0.3725^{*}$ & $-0.4505^{*}$ & $-0.0274 *$ & $-0.0506^{*}$ & $-0.0396 *$ & $-0.2242 *$ & $0.0192 *$ & $0.2087 *$ & 1 \\
\hline (12) GTA & $0.0455^{*}$ & $-0.0133^{*}$ & $0.0215^{*}$ & $0.0139 *$ & $0.0978 *$ & $0.1008 *$ & $0.1511 *$ & $0.1173^{*}$ & $0.0508 *$ & $0.0355^{*}$ & $-0.1024 *$ \\
\hline (13) $R G D P G R W$ & $0.0107 *$ & $0.0157 *$ & $0.0107 *$ & -0.0035 & $-0.1890 *$ & $-0.2179 *$ & $-0.2132 *$ & 0.0008 & 0.0034 & $-0.0068^{*}$ & $0.0210 *$ \\
\hline (14) FED FUNDS RATE & $0.0169 *$ & $0.0086^{*}$ & $0.0045^{*}$ & $0.0081 *$ & $-0.3073^{*}$ & $-0.2710 *$ & $-0.2576^{*}$ & 0.0017 & -0.0017 & $-0.0188^{*}$ & 0.0017 \\
\hline (15) COVID19 & $-0.0227 *$ & $-0.0418 *$ & $-0.0331 *$ & $-0.0212 *$ & $0.3984 *$ & $0.3779 *$ & $0.5931 *$ & -0.0012 & $0.0217 *$ & $0.0278 *$ & $-0.0636 *$ \\
\hline (16) CONS SENT & $-0.0279 *$ & $-0.0239 *$ & $-0.0221 *$ & $-0.0419 *$ & $-0.2582 *$ & $-0.3563 *$ & $-0.3880 *$ & 0.0009 & 0.0035 & $0.0083 *$ & $0.0562 *$ \\
\hline (18) TOBINS $Q$ & $-0.0439 *$ & $-0.0403 *$ & $-0.0425^{*}$ & $-0.0572 *$ & $-0.1904 *$ & $-0.1890 *$ & $-0.1773 *$ & $0.0673 *$ & $-0.0162 *$ & $0.0899 *$ & $0.0510 *$ \\
\hline (19) $N P L$ & $-0.3274 *$ & $-0.2182 *$ & $-0.2087 *$ & $-0.2865^{*}$ & $0.0749 *$ & $-0.0209 *$ & $0.0702 *$ & $0.0158 *$ & $0.0296 *$ & $0.0339 *$ & $0.2743^{*}$ \\
\hline (20) $L L P$ & $-0.2949 *$ & $-0.1789 *$ & $-0.1457^{*}$ & $-0.2158 *$ & $0.1599 *$ & $0.0860^{*}$ & $0.1654^{*}$ & $0.0907 *$ & $0.0562 *$ & $-0.0155^{*}$ & $-0.0199 *$ \\
\hline (21) TIERI & $0.1344 *$ & $0.2252 *$ & $-0.0407 *$ & $0.1379 *$ & $-0.0089 *$ & -0.0029 & $-0.0090 *$ & $-0.2359 *$ & $0.0658 *$ & $0.3565^{*}$ & $-0.0068 *$ \\
\hline (22) $R E G C A P$ & $0.1326^{*}$ & $0.2242 *$ & $-0.0411 *$ & $0.1365^{*}$ & $-0.0072 *$ & -0.0031 & $-0.0072 *$ & $-0.2268 *$ & $0.0681 *$ & $0.3572 *$ & $-0.0056^{*}$ \\
\hline (23) DEPLOANS & $-0.0147 *$ & $0.0209 *$ & $-0.0579 *$ & $-0.0082 *$ & 0.0005 & $-0.0270 *$ & 0.0017 & $-0.1545 *$ & $0.1351 *$ & $0.3808 *$ & $0.0856^{*}$ \\
\hline
\end{tabular}

* significance at 0.05 
Table A1 Continued: Correlations

\begin{tabular}{|c|c|c|c|c|c|c|c|c|c|c|c|c|}
\hline & (12) & (13) & (14) & (15) & (16) & (17) & (18) & (19) & (20) & (21) & (22) & \\
\hline (12) GTA & 1 & & & & & & & & & & & \\
\hline (13) $R G D P G R W$ & $-0.0156^{*}$ & 1 & & & & & & & & & & \\
\hline (14) FED FUNDS RATE & $-0.0590 *$ & $0.5622 *$ & 1 & & & & & & & & & \\
\hline (15) COVID19 & $0.2586^{*}$ & $-0.1438 *$ & $-0.1886^{*}$ & 1 & & & & & & & & \\
\hline (16) CONS SENT & $-0.0804 *$ & $0.5176^{*}$ & $0.4052 *$ & $-0.3995^{*}$ & 1 & & & & & & & \\
\hline (17) CASH FLOWS & $0.0093 *$ & $0.0634 *$ & $-0.0726^{*}$ & $0.0049 *$ & $0.0432 *$ & 1 & & & & & & \\
\hline (18) TOBINS $Q$ & $0.0256^{*}$ & $0.0478 *$ & $0.0116^{*}$ & $-0.0595 *$ & $0.0636 *$ & $-0.2525^{*}$ & 1 & & & & & \\
\hline (19) NPL & $-0.1861 *$ & $0.0069 *$ & $-0.0482 *$ & $-0.0677 *$ & $0.0409 *$ & $-0.0323 *$ & $0.0135^{*}$ & 1 & & & & \\
\hline (20) $L L P$ & $0.0129 *$ & $-0.0459 *$ & $-0.0841^{*}$ & $0.0336^{*}$ & $-0.0299 *$ & $0.0246^{*}$ & $-0.0350 *$ & $0.2549 *$ & 1 & & & \\
\hline (21) TIERI & $-0.0856^{*}$ & $0.0055^{*}$ & 0.0008 & $-0.0085^{*}$ & 0.0026 & $0.0090 *$ & -0.0042 & $-0.0309 *$ & $-0.0546^{*}$ & 1 & & \\
\hline (22) REG CAP & $-0.0883 *$ & $0.0055^{*}$ & -0.0002 & $-0.0083 *$ & 0.0029 & $0.0071 *$ & -0.0033 & $-0.0223 *$ & $-0.0491 *$ & $0.9987 *$ & 1 & \\
\hline (23) DEPLOANS & $-0.0441 *$ & $0.0048 *$ & $-0.0056^{*}$ & $-0.0137 *$ & $0.0249 *$ & $0.0264 *$ & -0.0033 & $-0.0073 *$ & $-0.0486^{*}$ & $0.5980 *$ & $0.5936 *$ & 1 \\
\hline
\end{tabular}

* significance at 0.05 
Figure A.1 The time-series evolution of EPU and bank stability

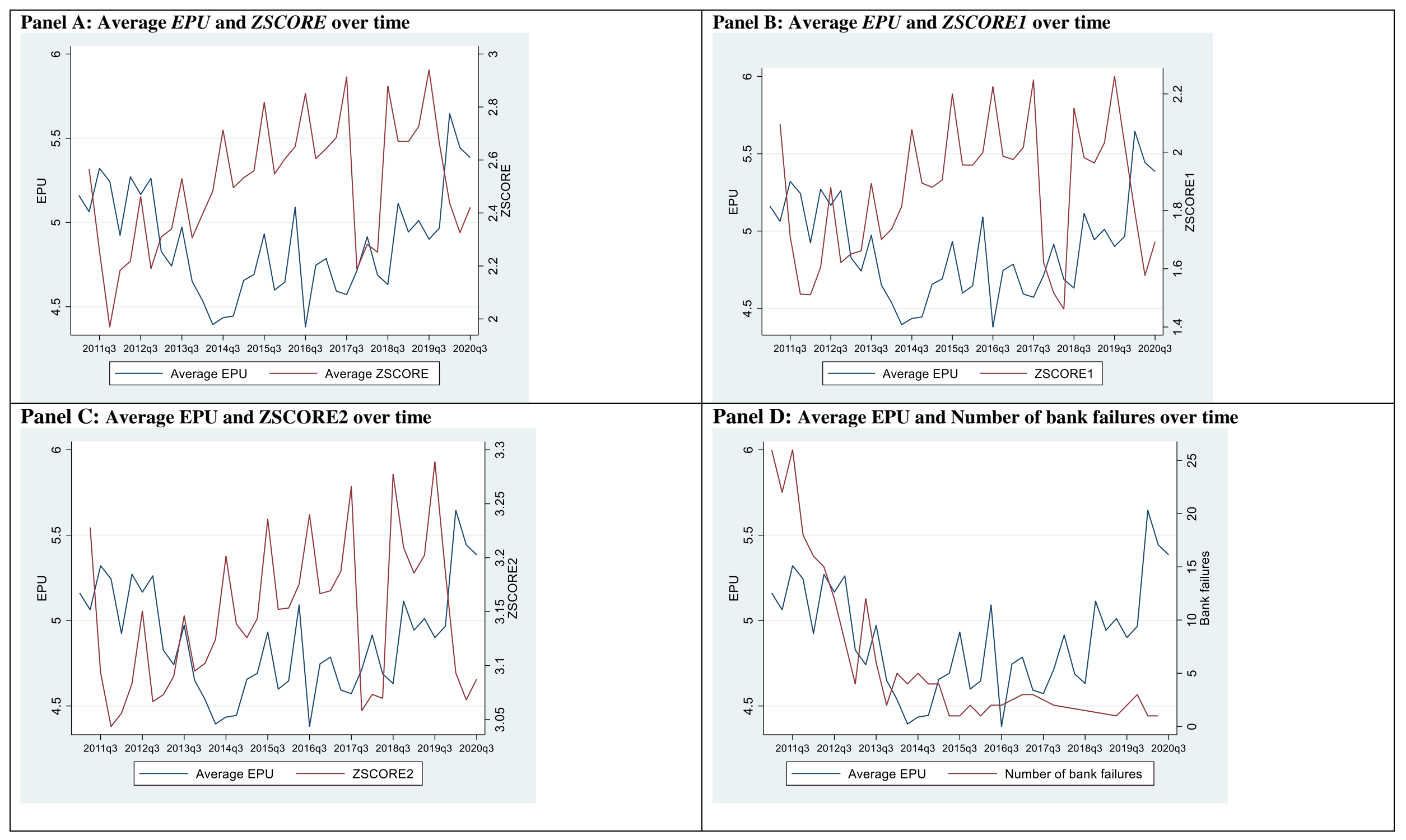


Note: This figure shows the time series evolution of EPU and bank stability in the US for the period 2011 Q1 and 2020 Q3. Panel A plots the quarterly comparison of average $E P U$ and average ZSCORE for our sample. EPU is the natural logarithm of the composite economic policy uncertainty measure for the US and its values are extracted from https://www.policyuncertainty.com. ZSCORE is generated using authors' own calculations and indicates the natural logarithm of the Z-score which is calculated as $(R O A+$ $E Q T A) / S D R O A$, where ROA is the return on assets, SDROA is the standard deviation of ROA, and EQTA is the equity to total assets ratio. Panel B and C plots for the components of ZSCORE, ZSCORE1 and ZSCORE2, respectively. ZSCORE1 indicates the risk-adjusted capitalization and calculated as the natural logarithm of EQTA / SD ROA; ZSCORE2 is the risk-adjusted return and calculated as the natural logarithm of ROA/SD ROA, respectively. Panel D shows the behavior of $E P U$ and the number of bank failures over time. Bank failure data is extracted from https://www.fdic.gov/resources/resolutions/bank-failures/failed-bank-list/ 
Figure A.2 The behavior of EPU and macro variables through time

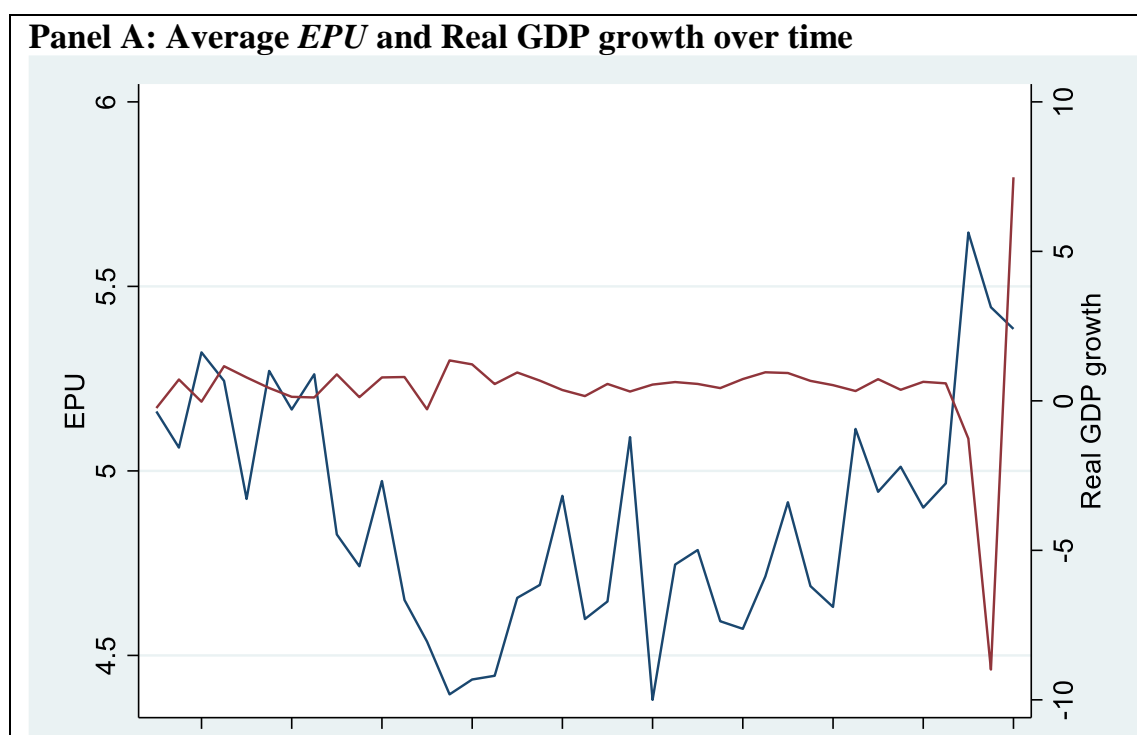

$2011 q 32012 q 32013 q 32014 q 32015 q 32016 q 32017 q 32018 q 32019 q 32020 q 3$
Panel B: Average EPU and Federal Funds rate over time

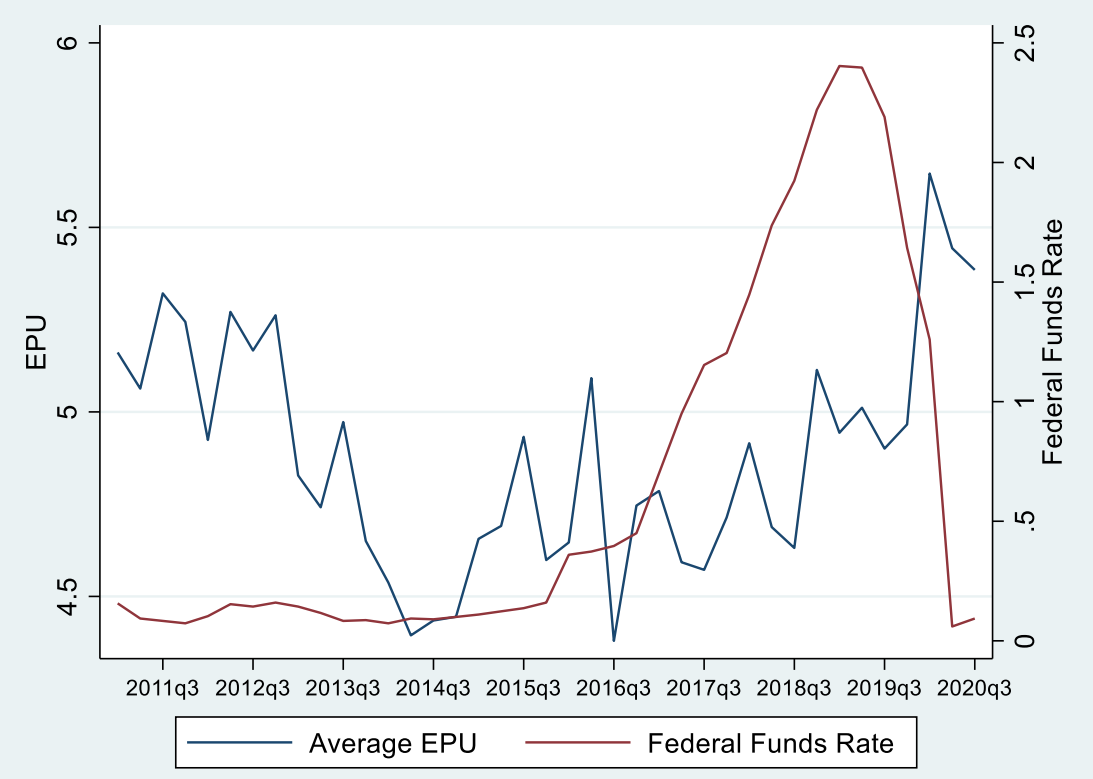

Note: This figure shows the time series behavior of EPU and some macroeconomic variables for the US between 2011 Q1 and 2020 Q3. Panel A plots the quarterly comparison of average EPU and real GDP growth. The real GDP growth is the quarterly real GDP growth and the data is extracted from the Federal Reserve Bank of St. Louis. EPU is the natural logarithm of the composite economic policy uncertainty measure for the US and its values are reached from https://www.policyuncertainty.com. Panel B shows the behavior of EPU and federal funds rate over time. The data for federal funds rate is taken from the Federal Reserve Bank of St. Louis. 